\title{
Cellular Localization of Huntingtin in Striatal and Cortical Neurons in Rats: Lack of Correlation with Neuronal Vulnerability in Huntington's Disease
}

\author{
Francesca R. Fusco, ${ }^{1}$ Quan Chen, ${ }^{1}$ William J. Lamoreaux, ${ }^{2}$ Griselle Figueredo-Cardenas, ${ }^{1}$ Yun Jiao, ${ }^{1}$ \\ Jonathan A. Coffman, ${ }^{1}$ D. James Surmeier, ${ }^{3}$ Marcia G. Honig, ${ }^{1}$ Leon R. Carlock, ${ }^{4}$ and Anton Reiner ${ }^{1}$ \\ ${ }^{1}$ Department of Anatomy and Neurobiology, College of Medicine, The University of Tennessee-Memphis, The Health \\ Sciences Center, Memphis, Tennessee 38163, 2Department of Biology, College of Staten Island, City University of New \\ York, Staten Island, New York 10314, ${ }^{3}$ Department of Physiology/Northwestern University Institute for Neuroscience, \\ Searle 5-474, Northwestern University Medical School, Chicago, Illinois 60611, and 4 Department of Molecular Biology \\ and Genetics, School of Medicine, Wayne State University, Detroit, Michigan 48201
}

Immunohistochemistry and single-cell RT-PCR were used to characterize the localization of huntingtin and/or its mRNA in the major types of striatal neurons and in corticostriatal projection neurons in rats. Single-label immunohistochemical studies revealed that striatum contains scattered large neurons rich in huntingtin and more numerous medium-sized neurons moderate in huntingtin. Double-label immunohistochemical studies showed that the large huntingtin-rich striatal neurons include nearly all cholinergic interneurons and some parvalbuminergic interneurons. Somatostatinergic striatal interneurons, which are medium in size, rarely contained huntingtin. Calbindin immunolabeling showed that the vast majority of the medium-sized striatal neurons that contain huntingtin are projection neurons, but only $\sim 65 \%$ of calbindin-labeled projection neurons (localized to the matrix compartment of striatum) were labeled for huntingtin. Calbindin-containing projection neurons of the matrix compartment and calbindin-negative projection neurons of the striatal patch compartment contained huntingtin with com- parable frequency. Single-cell RT-PCR confirmed that striatal cholinergic interneurons contain huntingtin, but only $\sim 65 \%$ of projection neurons contained detectable huntingtin message. The finding that huntingtin is not consistently found in striatal projection neurons [which die in Huntington's disease (HD)] but is abundant in striatal cholinergic interneurons (which survive in Huntington's disease) suggests that the mutation in huntingtin that causes HD may not directly kill neurons. In contrast to the heterogeneous expression of huntingtin in the different striatal neuron types, we found all corticostriatal neurons to be rich in huntingtin protein and mRNA. One possibility raised by our findings is that the HD mutation may render corticostriatal neurons destructive rather than render striatal neurons vulnerable.

Key words: striatum; huntingtin; corticostriatal neurons; Huntington's disease; cholinergic interneurons; striatal projection neurons
Huntington's disease (HD) is a dominant hereditary neurodegenerative disorder characterized by progressive cognitive decline and motor dysfunction (Bruyn and Went, 1986; Wilson et al., 1987; Albin and Tagle, 1995). The major site of neuron loss in $\mathrm{HD}$ is the striatal part of the basal ganglia, and it is this loss that accounts for the progressive movement disorder (Vonsattel et al., 1985; De La Monte et al., 1988; Hedreen et al., 1991; Storey et al., 1992). The disease process, however, does not affect striatal neurons uniformly. In general, striatal projection neurons die in HD (Reiner et al., 1988; Albin et al., 1990a,b, 1992; Kiyama et al., 1990; Richfield et al., 1995), whereas two major types of striatal interneurons, namely cholinergic interneurons and interneurons co-containing somatostatin, neuropeptide Y, and/or neuronal ni-

\footnotetext{
Received Aug. 3, 1998; revised Nov. 23, 1998; accepted Nov. 25, 1998.

This research was supported by National Institutes of Health Grants NS19620 and NS28721 (A.R.), a Cure Huntington's disease Contract from the Hereditary Disease Foundation (A.R.), National Institutes of Health Grant NS-26473 (D.J.S.), and a grant from the Consiglio Nazionale delle Ricerche of Italy (CNR074982) (F.F.).

Correspondence should be addressed to Dr. Anton Reiner, Department of Anatomy and Neurobiology, University of Tennessee-Memphis, 855 Monroe Avenue, Memphis, TN 38163.

Dr. Fusco's present address: Ospedale Di Riabilitazione S. Lucia, Istituto Di Ricovero E Cura A Carattere Scientifico, 00179 Roma, Italy.

Copyright (C) 1999 Society for Neuroscience $\quad 0270-6474 / 99 / 191189-14 \$ 05.00 / 0$
}

tric oxide synthase (NOS), survive (Ferrante et al., 1985, 1986, 1987a,b).

The mutated gene and the specific mutation responsible for HD have been known for several years (Huntington's Disease Collaborative Research Group, 1993). The gene itself is of unknown function, although several lines of evidence suggest that it is involved in intracellular vesicular trafficking (DiFiglia et al., 1995; Sharp et al., 1995; Wood et al., 1996). The mutation in the HD gene involves an expansion of a CAG repeat at the $5^{\prime}$ end of the HD gene beyond the normal 10-35 repeat range for this gene (Albin and Tagle, 1995). Discovery of the gene and gene defect responsible for HD offered the hope that studies of the localization of the HD gene mRNA and the HD protein (termed huntingtin) would provide insight into the pathogenesis and regional selectivity of the disease, but as of yet such studies have made the pathogenesis of HD more of a mystery. Both huntingtin protein and mRNA are widespread in bodily tissues and in the CNS ( $\mathrm{Li}$ et al., 1993; DiFiglia et al., 1995; Sharp et al., 1995; Bhide et al., 1996; Gourfinkel-An et al., 1997). Furthermore, huntingtin and its mRNA are less abundant in the striatum than in many other brain regions. Additionally, studies of postmortem HD tissue indicate that huntingtin protein and mRNA abundance in surviving striatal neurons is not obviously altered by the mutation or the 
disease process (Landwehrmeyer et al., 1995; Schilling et al., 1995; Trottier et al., 1995; Gourfinkel-An et al., 1997; Sapp et al., 1997), although the N-terminal fragment of huntingtin appears to be cleaved and translocated to the nucleus in some cortical and striatal neurons in at least those HD victims with a high number of CAG repeats (DiFiglia et al., 1997).

Several studies have examined the localization of normal huntingtin and its mRNA in the different types of striatal neurons in rats and humans, in part to help clarify the selectivity of HD for striatal projection neurons over striatal interneurons (Gutekunst et al., 1995; Landwehrmeyer et al., 1995; Ferrante et al., 1997; Kosinski et al., 1997; Sapp et al., 1997). These studies however, have yielded conflicting results. To help clarify the relationship between the localization of huntingtin in striatal neurons and HD pathogenesis, we performed the present studies in which we used several different antisera against huntingtin and sensitive immunohistochemical methods as well as single-cell RT-PCR methodology. We additionally explored the abundance of huntingtin in corticostriatal projection neurons because of the various lines of evidence implicating an excitotoxic process in HD pathogenesis (Beal et al., 1986, 1988, 1991; Young et al., 1988; FigueredoCardenas et al., 1994, 1997; Huang et al., 1995). Our findings indicate that although all corticostriatal neurons are rich in huntingtin, huntingtin abundance in the different kinds of striatal neurons is not consistently correlated with vulnerability to HD. These results raise the possibility that the gene defect in HD may not directly kill striatal neurons that produce defective huntingtin, but rather it may render corticostriatal neurons destructive to the striatum.

\section{MATERIALS AND METHODS}

Subjects. Male Wistar rats (140-275 gm; Harlan, Indianapolis, IN) were used in the present immunohistochemical studies, whereas young Sprague Dawley rats (3-4 weeks old; Harlan) were used for the singlecell RT-PCR studies. All studies were conducted in accordance with National Institutes of Health and Society for Neuroscience policies on the ethical use of animals in research.

Fluorogold injection. Corticostriatal projection neurons were retrogradely labeled by injections of fluorogold into the striatum, using previously described stereotaxic methods (Anderson and Reiner, 1991; Figueredo-Cardenas et al., 1994). These rats were killed 2-3 weeks later and processed for immunofluorescent visualization of huntingtin in corticostriatal neurons using the tyramide signal amplification method, as detailed below.

Tissue fixation. Under deep anesthesia ( $0.5 \mathrm{ml}$ of $35 \%$ chloral hydrate), rats injected with fluorogold or used for immunohistochemistry were perfused transcardially through the ascending aorta with $60 \mathrm{ml}$ of $6 \%$ dextran in $0.1 \mathrm{M}$ sodium phosphate buffer at $\mathrm{pH} 7.4$ (PB) followed by 200 $\mathrm{ml}$ of $4 \%$ paraformaldehyde, $0.1 \mathrm{M}$ lysine $-0.1 \mathrm{M}$ sodium periodate in 0.1 м PB. The brains were removed and post-fixed overnight at $4^{\circ} \mathrm{C}$, and then stored for $24 \mathrm{hr}$ in a $20 \%$ sucrose $/ 10 \%$ glycerol solution at $4^{\circ} \mathrm{C}$. The fixed brains were sectioned frozen on a sliding microtome in the transverse plane at $40 \mu \mathrm{m}$. Each brain was collected as $6-12$ separate series in 0.1 M PB- $0.02 \%$ sodium azide and stored until processed for immunohistochemistry. In some cases, immunolabeling was enhanced by pretreating the free-floating sections with a $30 \mathrm{~min}$ immersion in $10 \mathrm{~mm}$ sodium citrate buffer, $\mathrm{pH} 9.0$, at $85^{\circ} \mathrm{C}$. Such treatment has been shown to enhance antigenicity of fixed tissue for various antigens (Evers and Eylings, 1994).

Immunohistochemical single labeling. The immunohistochemical single labeling was performed using immunofluorescence or the peroxidaseantiperoxidase (PAP) procedure, as described previously (Anderson and Reiner, 1990, 1991; Figuredo-Cardenas et al., 1994), or according to the tyramide signal amplification method (Bobrow et al., 1989, 1991; Adams, 1992; Berghorn et al., 1994). A set of four mouse monoclonal antibodies [mAb2166, mAb2168, mAb2170, and mAb2172; obtained from Chemicon (Temecula, CA)] and one rabbit polyclonal antiserum (Ab519; generated by L. R. Carlock) against human huntingtin were used. The antibodies were generated against different fragments of human huntingtin as follows: (1) mAb2166, aa181-812; (2) mAb2168, aa2416-2541; (3)
mAb2170, aa1247-1646; (4) mAb2172, aa2683-2979; and (5) rAb519, aa1188-1204. The specificity of these antibodies against huntingtin (both rodent and human) was demonstrated previously (Bessert et al., 1995; Trottier et al., 1995) and was confirmed by us for rat huntingtin using Western blots of rat brain homogenates, which showed that each antibody bound to a single protein of the molecular weight of huntingtin. Primary antiserum omission controls, normal mouse and rabbit serum controls, and preimmune serum controls were used to further confirm the specificity of our immunohistochemical labeling.

For all immunohistochemical methods used, sections were incubated for $72 \mathrm{hr}$ at $4^{\circ} \mathrm{C}$ in primary antiserum diluted 1:100-1:500 with $0.3 \%$ Triton X-100/0.02\% sodium azide/ $0.1 \mathrm{M}$ PB (PBX). After several rinses in $\mathrm{PB}$, the sections processed for immunofluorescence were incubated for $1 \mathrm{hr}$ at room temperature in tetramethylrhodamine isothiocyanate (TRITC)-conjugated or dichlorotriazinylamino-fluorescein (DTAF)conjugated secondary antiserum (donkey anti-mouse or anti-rabbit IgG) (Jackson Immunoresearch, West Grove, PA), diluted 1:50 in PBX. The labeled tissue was then rinsed in PB, mounted on gelatin-coated slides, and coverslipped with 9:1 glycerin/0.05 M carbonate buffer or 9:1 glycerol/PB-saline containing $p$-phenylenediamine. The distribution of labeling was assessed using an Olympus epi-illumination fluorescence microscopy system. A Bio-Rad MRC-1000 confocal laser scanning microscope (CLSM) was also used for this purpose, as well as to evaluate labeling intensity.

For the PAP procedure, after incubation in primary antiserum, sections were incubated in goat or donkey anti-rabbit IgG or anti-mouse $\operatorname{IgG}$ diluted 1:50 in PBX, followed by incubation in the appropriate mouse or rabbit PAP complex diluted 1:100 in PBX, each at room temperature for $1 \mathrm{hr}$. Subsequent to the PAP incubation, the sections were reacted for peroxidase visualization by incubation in $50 \mathrm{ml}$ of $0.05 \mathrm{M}$ imidazole $/ 0.05$ $\mathrm{M}$ cacodylate buffer, $\mathrm{pH} 7.2$, containing $50 \mathrm{mg}$ diaminobenzidine tetrahydrochloride (DAB) for $10 \mathrm{~min}$, and then adding $200 \mu \mathrm{l}$ of $3 \%$ hydrogen peroxide for an additional $10 \mathrm{~min}$, with continuous agitation throughout. The PAP/DAB-labeled sections were then washed in distilled water, placed in $0.1 \mathrm{M} \mathrm{PB}$, mounted onto gelatin-coated slides, dried, dehydrated, and coverslipped with Permount.

For the tyramide signal amplification (TSA) method, after incubation in primary antiserum, sections were sequentially incubated in biotinylated goat anti-rabbit IgG or biotinylated anti-mouse IgG diluted 1:501:200 in PBX, followed by incubation in streptavidin-conjugated peroxidase diluted 1:50-1:200 in PBX, each at room temperature for $1 \mathrm{hr}$. The sections were then incubated in TRITC-conjugated tyramide or biotinylated tyramide at room temperature for $10-15 \mathrm{~min}$. The TRITCtyramide-labeled tissue was mounted on gelatin-coated slides, coverslipped, and viewed as described above for the immunofluorescent material. The tissue labeled with biotinylated tyramide was incubated for $1 \mathrm{hr}$ incubation at room temperature in streptavidin-peroxidase. This peroxidase labeling was visualized with $\mathrm{DAB}$ as described above for PAP/DAB labeling, and the labeled sections were mounted, dehydrated, coverslipped, and examined.

Immunohistochemical double labeling. Sections were immunohistochemically double-labeled for huntingtin and a striatal neuron typespecific marker. The type specific markers were as follows: (1) choline acetyltransferase (ChAT) for cholinergic striatal interneurons; (2) parvalbumin (PARV) for the large GABAergic/parvalbuminergic striatal interneurons (Cowan et al., 1990; Kita et al., 1990); (3) somatostatin (SS) for the striatal interneurons co-containing SS, neuropeptide $\mathrm{Y}$, and neuronal nitric oxide synthase (Figueredo-Cardenas et al., 1997); or (4) calbindin (CALB) for striatal matrix projection neurons (FigueredoCardenas et al., 1998). To carry out the immunohistochemical double labeling, sections were incubated for $72 \mathrm{hr}$ at $4^{\circ} \mathrm{C}$ in the two primary antibodies diluted with PBX. Any of three mouse anti-huntingtin antibodies (mAb2166, mAb2168, or mAb2170) was used at a dilution of 1:200. The neuron type-specific primary antisera, their sources, and the antisera dilutions were as follows: (1) goat anti-CHAT (Chemicon), 1:500; (2) rabbit anti-PARV (Sigma, St. Louis, MO), 1:1000; (3) rabbit anti-SS (Incstar, Stillwater, MN), 1:500; and (4) rabbit anti-CALB (Sigma), 1:200. The specificity and efficacy of these antisera have been described previously or were confirmed here (Figueredo-Cardenas et al., 1994, 1997, 1998). Tissue incubations were performed by first incubating the tissue for $48-72 \mathrm{hr}$ at $4^{\circ} \mathrm{C}$ in a primary antisera mixture containing an antibody against huntingtin and one against one of the striatal cell type-specific markers. After they were rinsed, the sections were then sequentially incubated in biotinylated goat anti-mouse IgG diluted 1:501:200 in PBX, followed by incubation in streptavidin-conjugated perox- 

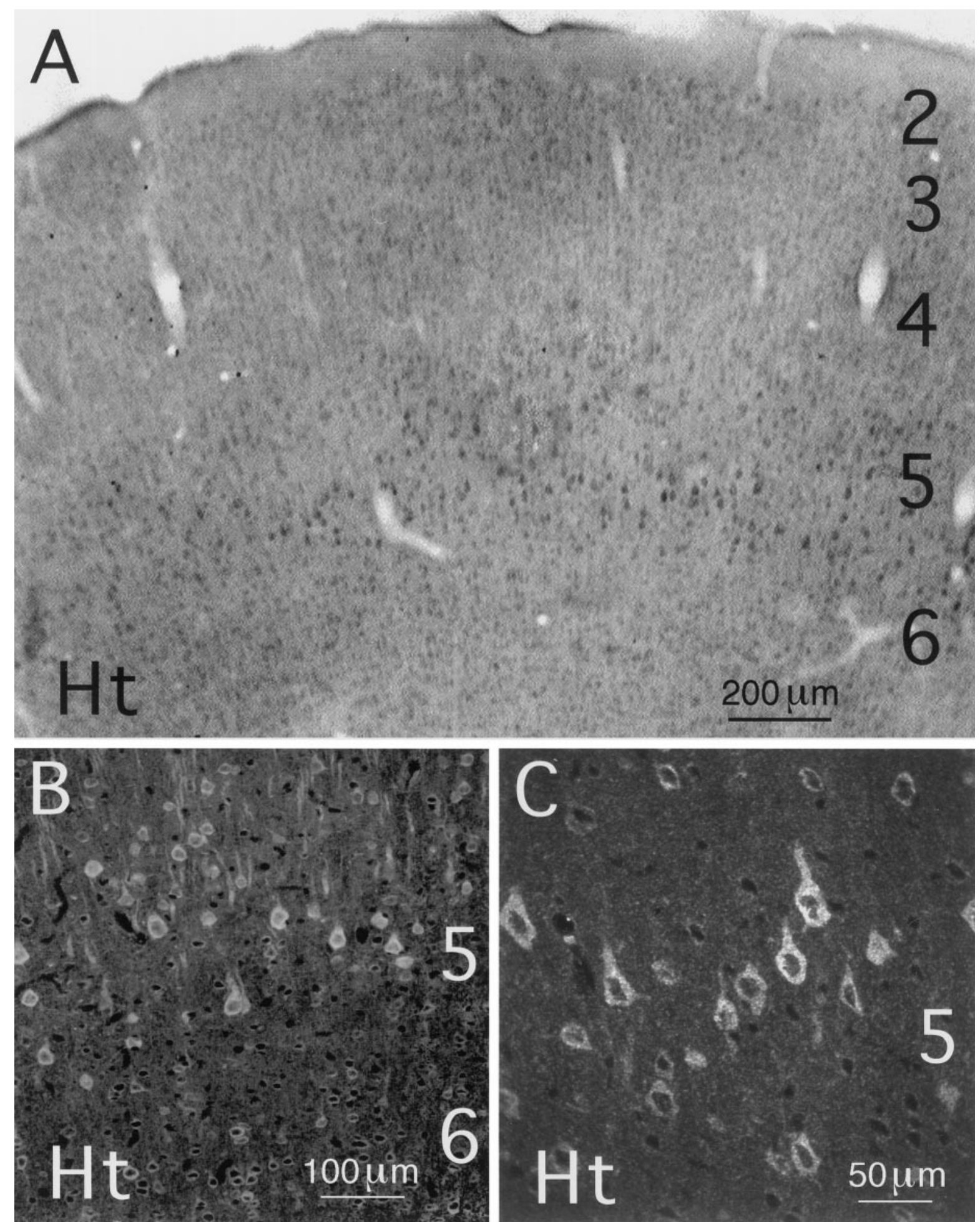

Figure 1. Immunolabeling for huntingtin $(H t)$ in rat cortex. $A$, Low-magnification view of motor cortex in PAP/DAB-immunolabeled tissue. Note that perikaryal labeling for huntingtin is most prominent in layer 5 of cortex. $B, C$, CLSM views of cortex at increasingly higher magnification in tissue labeled for huntingtin using immunofluorescence. Both fields show intense labeling of pyramidal neurons in layer 5 of cortex. The following anti-huntingtin antibodies were used to label the tissue shown in these images: mAb2168 $(A)$ and mAb2166 $(B, C)$. The TSA method was used for $B$ and $C$.

idase diluted 1:50-1:200 in PBX, each at room temperature for $1 \mathrm{hr}$. The sections were then incubated in TRITC-conjugated tyramide at room temperature for $1 \mathrm{hr}$. The tissue was subsequently incubated in a secondary antiserum specific for the neuron type-specific antiserum conjugated to DTAF at a 1:50 dilution. The fluorescently labeled sections were mounted on gelatin-coated slides, coverslipped, and viewed as described above for the immunofluorescent material.
Quantification of double labeling. The immunohistochemically doublelabeled tissue was used to determine the percentage of the CHAT + , $\mathrm{PARV}+, \mathrm{SS}+$, and $\mathrm{CALB}+$ striatal neurons that were huntingtinlabeled. For CHAT-huntingtin, PARV-huntingtin, and SS-huntingtin double-labeling, all striatal neurons labeled for the neuronal marker (CHAT, PARV, or SS) were examined in each hemisphere in each of three to four rostrocaudally spaced sections in each of three to four rats. 

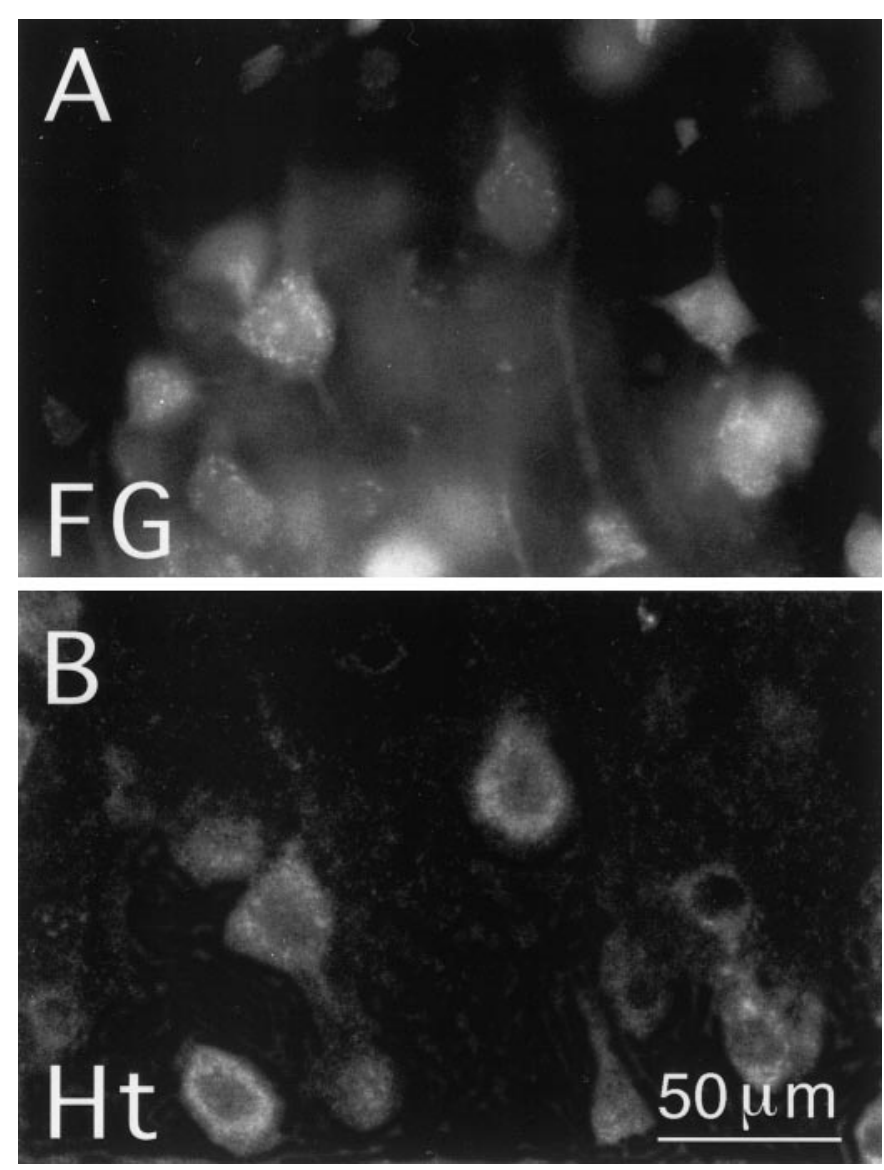

Figure 2. Layer 5 corticostriatal projection neurons in rat as identified by retrograde labeling with fluorogold. $A$ shows retrograde fluorogold labeling and $B$ shows TSA immunofluorescence labeling for huntingtin $(H t$; with $\mathrm{mAb} 2170)$ in this same field. Note that the pyramidal neurons retrogradely labeled from striatum with fluorogold are also well labeled for Ht. Magnification in $A$ is same as in $B$.

For CALB-huntingtin double-labeled tissue, three separate fields (one dorsolateral, one central, and one medial, each $0.8 \mathrm{~mm}$ in diameter) on each side of the brain in each of three rostrocaudally spaced sections in each of three rats were examined. The mAb2166 was used for some rats, whereas the mAb2170 was used in others. The number of CHAT+, $\mathrm{PARV}+, \mathrm{SS}+$, or CALB + striatal neurons that also labeled for huntingtin or that were devoid of huntingtin labeling were counted in each case. A percentage of neurons that contained huntingtin labeling for each neuronal marker was calculated for each animal. Because the results were highly similar regardless of whether the mAb2166 or the mAb2170 was used, a mean percentage for all animals for each marker was then calculated. For the fluorogold retrograde labeling study, fluorogoldlabeled and fluorogold-huntingtin double-labeled cortical neurons in layer 5 were counted in both hemispheres in each of three $0.8-\mathrm{mm}$ diameter fields in each of two sections from one rat with extensive labeling of corticostriatal projection neurons. The fields that were examined sampled an equally spaced medial-to-lateral series of cortical fields. All counts of labeled neurons were restricted to the upper plane of focus, because the huntingtin labeling of perikarya was largely restricted to the outer few micrometers of tissue surface, presumably because of limitation in the penetration of the reagents.

Single-cell RT-PCR. The single-cell RT-PCR analysis was performed as described previously (Surmeier et al., 1996; Chen et al., 1997). Young adult Sprague Dawley rats (3-4 weeks old) were anesthetized with methoxyflurane and decapitated. Coronal brain sections (400 $\mu \mathrm{m}$ thick) were obtained and kept at room temperature in $95 \% \mathrm{O}_{2} / 5 \% \mathrm{CO}_{2}-$ bubbled $\mathrm{NaHCO}_{3}$-buffered saline solution, $\mathrm{pH} 7.4$, containing (in $\mathrm{mM}$ ): $126 \mathrm{NaCl}, 2.5 \mathrm{KCl}, 2 \mathrm{CaCl}_{2}, 2 \mathrm{MgCl}_{2}, 26 \mathrm{NaHCO}_{3}, 1.25 \mathrm{NaH}_{2} \mathrm{PO}_{4}, 1$ pyruvic acid, 0.2 ascorbic acid, $0.1 N G$-nitro-L-arginine, 1 kynurenic acid, and 10 glucose. The dorsal striatum or a piece of cortex was then dissected out from the slices and transferred into oxygenated protease $(1.5 \mathrm{mg} / \mathrm{ml}$; Sigma) in HBSS. After a $35 \mathrm{~min}$ treatment with protease, the striatal or cortical tissue was mechanically dissociated by triturating with Pasteur pipettes. The acutely dissociated striatal or cortical neurons then were plated on a culture dish, which was mounted on the stage of an inverted microscope and perfused continuously with the control saline. Neurons were patch-clamped with an electrode filled with $5 \mu$ l of DEPCtreated water. An effort was made to harvest both large and mediumsized striatal neurons, so that both cholinergic interneurons and projection neurons would be sampled, whereas pyramidal cells, as identified by their distinctive size and morphology, were specifically harvested in the cortical dissociates. Positive pressure was maintained on the electrode during the approach to avoid entry of cellular debris. After the rupture of the membrane patch, the electrode and attached cell were lifted, and the cell was sucked into the electrode. The tip of the electrode was broken, and the contents were expelled into an Eppendorf tube containing $5 \mu \mathrm{l}$ of $\mathrm{H}_{2} \mathrm{O}, 0.5 \mu \mathrm{l}$ of RNAsin, and $0.5 \mu \mathrm{l}$ of $0.1 \mathrm{~m}$ DTT. The RT reaction was performed using the SuperScript Preamplification System (Life Technologies, Grand Island, NY) according to the manufacturer's protocol. The synthesized first-strand cDNAs from the RT reaction were stored at $-80^{\circ} \mathrm{C}$ until use in PCR analysis.

The PCR procedure was performed as described previously (Surmeier et al., 1996; Chen et al., 1997). Thin-walled PCR tubes that contained a mixture of first-strand cDNA template, $10 \times$ PCR buffer $(5 \mu \mathrm{l}), 25 \mathrm{~mm}$ $\mathrm{Mg}^{2+}(5 \mu \mathrm{l}), 25 \mathrm{mM}$ dNTPs $(1 \mu \mathrm{l}), 20 \mu \mathrm{M}$ primers $(2.5 \mu \mathrm{l})$, and $2.5 \mathrm{U} \mathrm{Taq}$ DNA polymerase were used. The final reaction volume was adjusted to $50 \mu \mathrm{l}$ with DEPC-treated water. The Taq enzyme, PCR buffer, $\mathrm{Mg}^{2+}$ solution, and four dNTPs were all purchased from Promega (Madison, WI). Amplification was performed on a thermal cycler (MJ Research, Watertown, MA) under the following cycle conditions: denaturation at $94^{\circ} \mathrm{C}$ for $1 \mathrm{~min}$, annealing at $56^{\circ} \mathrm{C}$ for $1 \mathrm{~min}$, and extension at $72^{\circ} \mathrm{C}$ for 1.5 min for a total 45 cycles. After PCR amplification, an $8.5 \mu \mathrm{l}$ aliquot of reaction product was analyzed by electrophoresis on ethidium bromidestained $1.5 \%$ agarose gels. In representative cases, amplicons were purified from the gel (QIAquick Gel Extraction Kit, QIAGEN) and sequenced by the University of Tennessee Molecular Resource Center (Memphis, TN ) or St. Jude Children's Research Hospital Molecular Resource Center (Memphis, TN). These sequences were found to match published sequences, thereby confirming amplification of the intended gene product.

All cells were typed as to whether they contained detectable huntingtin mRNA. In addition, all striatal medium-sized cells were typed as to whether they contained substance P (SP) and/or enkephalin (ENK) mRNA, and large striatal cells were typed as to whether they contained CHAT mRNA. The primers for the detection of huntingtin cDNAs were 5'-CCTTTGGCCTATGAGATCTGGATGTG-3' and 5'-TCGTACCACCATTTGTTTTTCA-3'. The amplified huntingtin cDNA product has a size of $519 \mathrm{bp}$. Five microliters of cDNA template were used for the huntingtin PCR. For cells showing a negative result for huntingtin cDNA product, PCR was performed a second time using twice as much cDNA as the first time. The primers for the detection of ENK cDNA were 5'-AACAGGATGAGAGCCACTTGC-3' and 5'-CTTCATCCGAGGGTAGAGACT-3'. The amplified ENK cDNA product has a size of $476 \mathrm{bp}$. The primers for SP were $5^{\prime}$-TGAGCATCTTCTTCAGAGAATCGC-3' and $5^{\prime}$-ATCGCTGGCAAACTTGTACAACTC-3'. The amplified products for SP have a size of 513 and/or 468 bp (depending on the mRNA splice variants present). Two to five microliters of cDNA template were used for the SP and ENK-PCR. The primers for the detection of CHAT cDNA were 5'-ATGGCCATTGACAACCATCTTCTG-3' and 5' CCTTGAACTGCAGAGGTCTCTCAT- ${ }^{\prime}$. The amplified CHAT cDNA product has a size of $324 \mathrm{bp}$. Five to ten microliters of cDNA template were used for the ChAT PCR. PCR reactions were performed following procedures designed to minimize the chances of cross-contamination (Cimino et al., 1990). Negative controls for contamination from extraneous and genomic DNA were run for every batch of neurons. Contamination from extraneous sources was checked by replacing the cellular template with water. To ensure that genomic DNA did not contribute to the PCR products, neurons were aspirated and processed in the normal manner except that the reverse transcriptase was omitted. Both controls were consistently negative in these experiments.

\section{RESULTS}

\section{Antisera and immunohistochemical labeling methods}

Similar labeling patterns were observed with all five antibodies and by all immunohistochemical labeling methods used. For this 


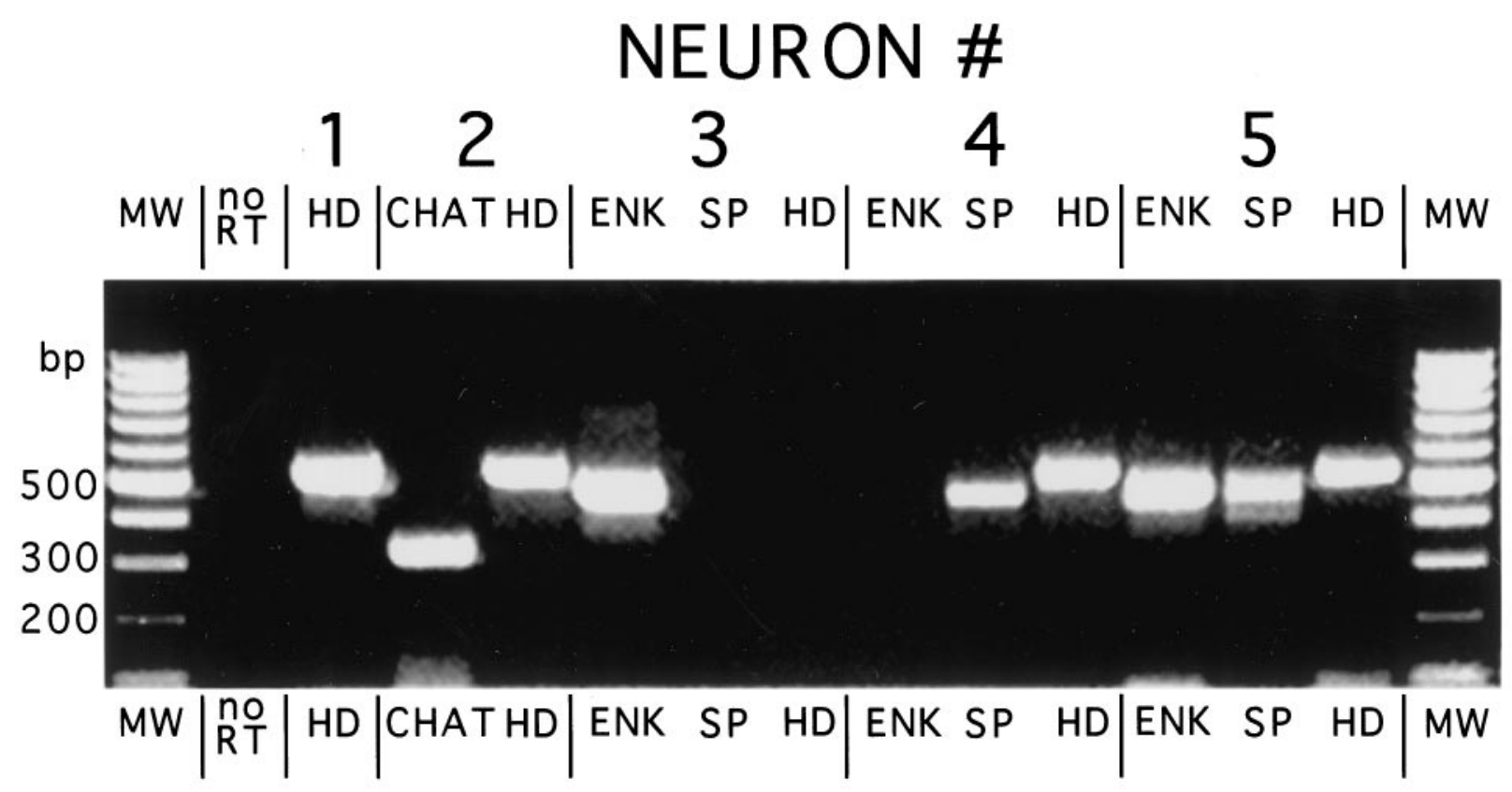

Figure 3. An ethidium bromide-stained agarose gel showing single-cell RT-PCR data for a cortical pyramidal and four striatal neurons in rat. The mRNA harvested from single neurons was reverse-transcribed into cDNA, and the cDNA was used as a template to PCR-amplify an HD gene-specific DNA fragment. Cortical pyramidal cells were identified by their distinctive morphology before aspiration. Striatal cholinergic interneurons were identified by expression of CHAT mRNA, whereas projection neurons were identified by expression of ENK or SP mRNAs or both. For each of the five neurons shown, one lane shows the HD gene PCR signal, whereas for the striatal neurons additional lanes show signals for the neuron type-specific markers. The identified cortical pyramidal neuron shows a PCR signal for HD message (NEURON \#1), the striatal cholinergic neuron shows a PCR signal for HD message (NEURON \#2), the ENK + striatal projection neuron does not show a PCR signal for HD message (NEURON \#3), the SP+ striatal projection neuron shows a PCR signal for HD message (NEURON \#4), and the SP+/ENK + striatal projection neuron shows a PCR signal for HD message (NEURON \#5). The first and last lanes show the molecular weight $(M W)$ marker, whereas the second lane shows that omitting the RT step yields no HD gene product.

reason, no distinctions are made below in terms of which antiserum or antibody yielded which pattern. The rabbit polyclonal antiserum, however, did yield the highest background staining of all five antibodies, and the mAb 2172 yielded the lightest signal of the five antibodies used. In general, the labeling patterns were considerably more evident with TSA methods than with the conventional immunofluorescence and peroxidase-antiperoxidase methods.

\section{Cortex}

Many neurons in all layers of telencephalic cortex were labeled for huntingtin; however, pyramidal neurons in layer 5 were the most intensely and abundantly labeled (Fig. 1). For these cells, the huntingtin labeling was evident in the perikaryal cytoplasm and proximal dendrites (Fig. 1). The nuclei of the huntingtinlabeled cortical neurons were devoid of labeling, and the cytoplasmic labeling typically had a granular appearance. Because pyramidal neurons in layer 5 of cortex project to striatum (Goldman-Rakic and Selemon, 1986; Wilson, 1987), we combined retrograde labeling with immunolabeling for huntingtin to determine whether the intensely huntingtin-labeled neurons in layer 5 included corticostriatal projection neurons. Injection of fluorogold into the striatum labeled numerous neurons in layers 3 and 5 throughout cortex, all of which were rich or extremely rich in huntingtin (Fig. 2). Ten cortical pyramidal cells were characterized by single-cell RT-PCR analysis to determine whether they contained mRNA for the HD gene (Fig. 3). All 10 cortical neurons that we had identified as layer 5 pyramidal neurons by their size and shape yielded a robust, positive PCR signal for a cDNA fragment that was the predicted size for the HD gene PCR product, thereby indicating that these cells contained mRNA coding for huntingtin (Fig. 3).

\section{Striatum}

A uniform scattering of large neurons that were intensely labeled for huntingtin and numerous medium-sized neurons moderately labeled for huntingtin were observed in the striatum. In all cells, granular labeling was evident in the perikaryal cytoplasm and proximal dendrites, and the nucleus was devoid of huntingtin labeling (Fig. 4). No unambiguous labeling of axons or terminals was observed, although the striatal neuropil possessed a dense mat of fine punctate labeling, particularly in the material labeled by the tyramide signal amplification method. The distribution of huntingtin-labeling of perikarya and neuropil was uniform in striatum, suggesting that the patch and matrix compartments of striatum possessed no major differences in huntingtin localization.

Double labeling revealed that nearly all $\mathrm{CHAT}+$ striatal interneurons $(99.0 \%)$ were intensely labeled for huntingtin (Fig. 5, Table 1). In addition, the vast majority of the striatal neurons intensely labeled for huntingtin were $\mathrm{CHAT}+$. That cholinergic striatal interneurons contain huntingtin was confirmed by singlecell RT-PCR analysis (Fig. 2). All 10 of the large striatal neurons that we examined contained CHAT mRNA and thus were striatal cholinergic interneurons, and all yielded a robust, positive PCR signal for huntingtin mRNA. Many of the remaining large huntingtin-rich striatal neurons are $\mathrm{PARV}+$ interneurons, because $\sim 17.8 \%$ of the PARV+ neurons were found to be rich in huntingtin (Fig. 6A,B, Table 1). The remaining PARV+ interneurons, however, were only moderately or lightly labeled for huntingtin. By contrast to the cholinergic and parvalbuminergic 

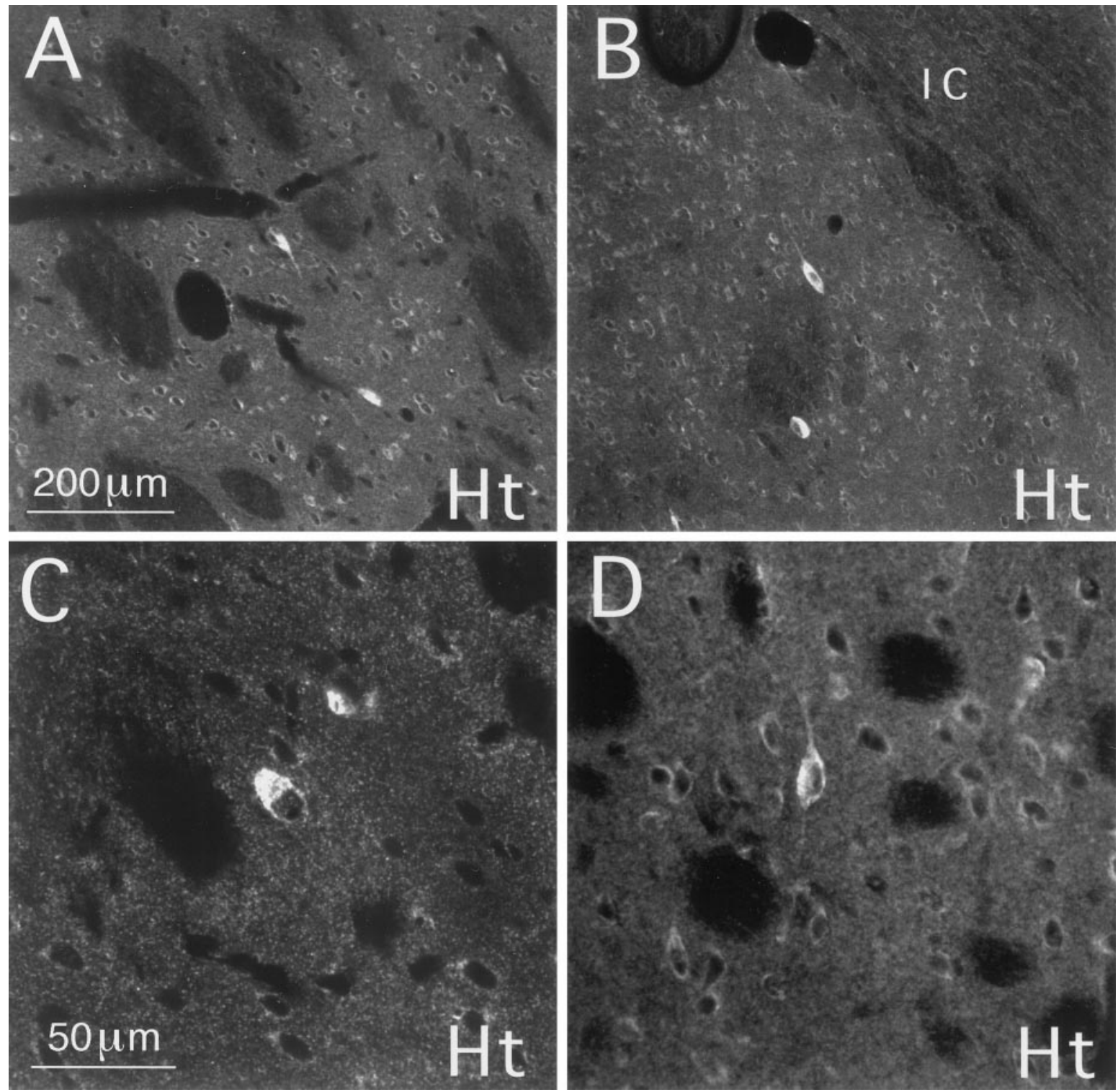

Figure 4. Immunofluorescence labeling for huntingtin $(H t)$ in the rat striatum viewed with CLSM. Two low-magnification fields $(A, B)$ and two high-magnification fields $(C, D)$ show that scattered large neurons intensely labeled for huntingtin and numerous medium-sized neurons moderately labeled for huntingtin are present in striatum. The TSA method and the following anti-huntingtin antibodies were used to label the tissue shown in these images: mAb2166 $(A, B, D)$; mAb2168 $(C)$. Magnification in $A$ is as in $B$; magnification in $C$ is as in $D$.

interneurons, the SS+ striatal interneurons, which are mediumsized, were typically devoid of huntingtin ( $1.9 \%$ contained huntingtin) (Fig. 6C,D, Table 1).

To assess the prevalence of huntingtin among striatal projection neurons, we used calbindin (CALB) immunolabeling to identify striatal projection neurons in the matrix compartment. We found that only $63.8 \%$ of the CALB + matrix compartment neurons were immunolabeled for huntingtin, and all of these were moderate in huntingtin (Fig. $7 A, B$, Table 1). The abundance of huntingtin-immunolabeled perikarya and their labeling intensity were no different in the CALB-poor patch compartment of striatum than in the CALB-rich matrix, thus suggesting that patch compartment projection neurons contain huntingtin with the same frequency as matrix compartment projection neurons (Fig. $7 C, D)$. However, an exact percentage of patch neurons containing huntingtin could not be determined, because we had no independent marker of projection neurons in the patch compartment.
Fifty-one medium-sized striatal neurons were characterized by single-cell RT-PCR (Fig. 2). Each neuron could be positively identified as a projection neuron because it contained SP and/or ENK mRNA. Of these neurons, $62.7 \%$ contained huntingtin mRNA. This frequency corresponds well to the frequency of huntingtin in striatal projection neurons that we observed with immunolabeling.

The individually sampled medium-sized striatal neurons were then categorized into three projection neuron types as follows: (1) neurons containing only ENK mRNA (ENK+), which are known to predominantly project to globus pallidus (Reiner and Anderson, 1990); (2) neurons containing only SP mRNA (SP+), which are known to project to the entopeduncular nucleus and substantia nigra (Kawaguchi et al., 1990; Reiner and Anderson, 1990); and (3) neurons containing both ENK and SP mRNAs $(\mathrm{ENK}+/ \mathrm{SP}+)$, which appear to preferentially project to the substantia nigra (Surmeier et al., 1992, 1996). Our single-cell RT- 

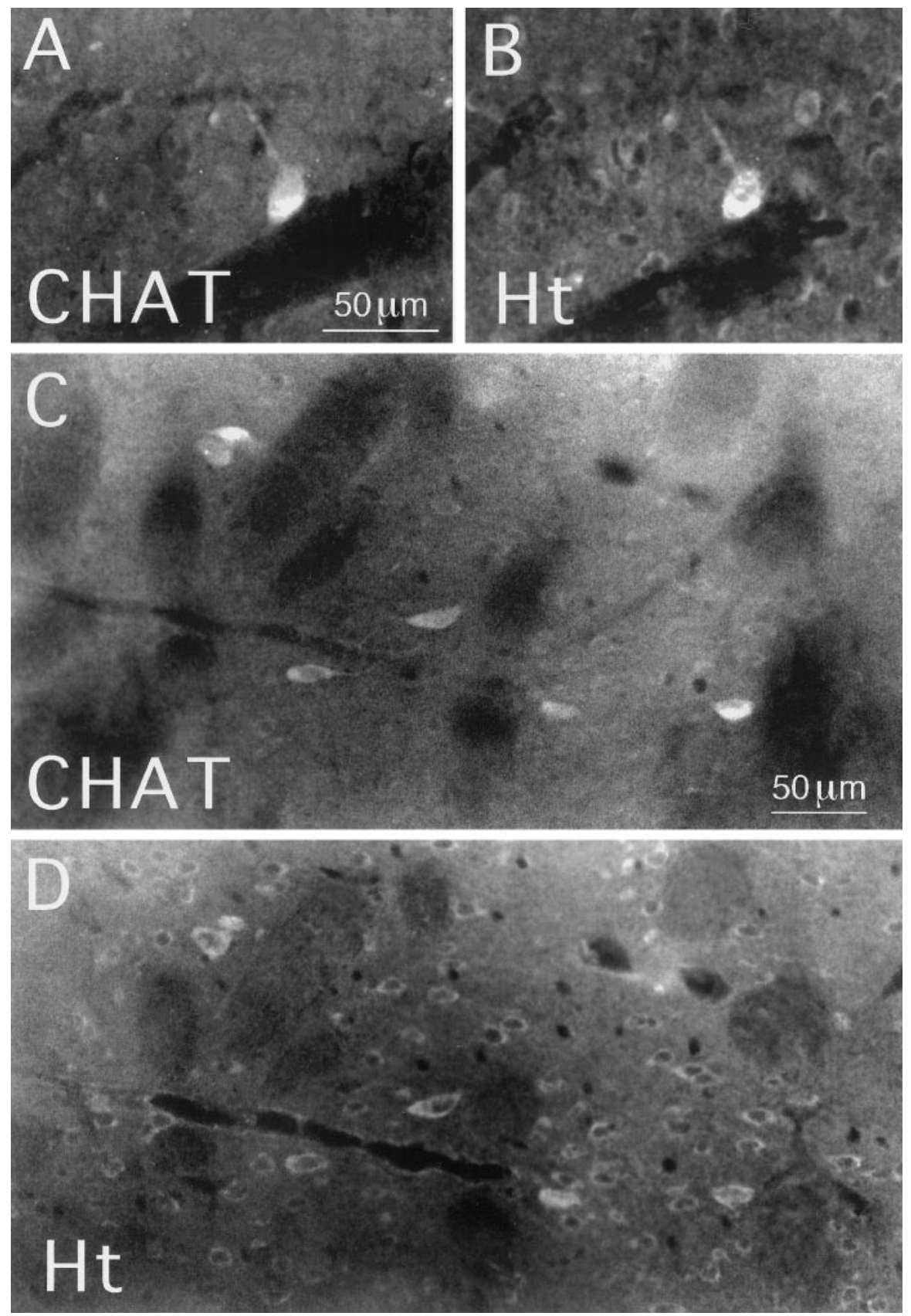

Figure 5. Huntingtin $(\mathrm{Ht})$ localization in striatal cholinergic interneurons in rat. Striatal tissue was double-labeled by immunofluorescence for the cholinergic marker CHAT $(A, C)$ and for huntingtin $(B$, $D$ ) and viewed using epi-illumination fluorescence microscopy. Large perikarya intensely labeled for CHAT in $A$ and $C$ are also intensely labeled for huntingtin, as shown in $B$ and $D$. Also note that many medium-sized perikarya that are unlabeled for CHAT in $A$ and $C$ are labeled for huntingtin in $B$ and $D$. The mAb2170 anti-huntingtin antibody and the TSA method were used to label the tissue shown in $B$ and $D$. Magnification in $A$ as in $B$; magnification in $C$ as in $D$.
PCR results showed that huntingtin mRNA was present in 9 of 16 $(56.25 \%) \mathrm{ENK}+$ neurons, 9 of $10(90 \%) \mathrm{SP}+$ neurons, and 14 of $25(56 \%) \mathrm{ENK}+/ \mathrm{SP}+$ neurons (Table 2).

\section{Basal telencephalon}

To further evaluate the relationship between huntingtin localization and neuronal vulnerability in $\mathrm{HD}$, we examined several additional basal telencephalic regions that survive well or relatively well in HD. We found that large neurons in globus pallidus, the entopeduncular nucleus, the ventral pallidum and the nucleus basalis of Meynert were intensely labeled for huntingtin (Fig. 8). All CHAT+ basal forebrain neurons examined by doublelabeling immunohistochemical methods were found to be intensely labeled for huntingtin (Table 1). Within globus pallidus, double-labeling studies revealed that $94 \%$ of the PARV + neurons contained huntingtin (Fig. 8C,D, Table 1).

\section{DISCUSSION}

The present results confirm and expand previous findings, indicating that endogenous huntingtin in rat telencephalon is a cytoplasmic protein that is localized to the perikarya and proximal dendrites of neurons and is most abundant in the larger neurons of cortex, striatum, and basal telencephalon (DiFiglia et al., 1995; Gutekunst et al., 1995; Bhide et al., 1996). Of particular note, our single-cell RT-PCR and immunohistochemical data show that huntingtin and its mRNA are uniformly abundant in striatal cholinergic interneurons, which are the largest of striatal neurons, and in the large pyramidal neurons of layer 5, many of which we found to be corticostriatal projection neurons. Huntingtin is also abundant in such large basal telencephalic neurons as those of globus pallidus, the entopeduncular nucleus, the basal nucleus of Meynert, and the ventral pallidum. In contrast, somatostatinergic 


\begin{tabular}{|c|c|c|c|}
\hline Marker & Cell type & $\%$ containing $\mathrm{Ht}$ & Survival in HD \\
\hline \multicolumn{4}{|l|}{ Striatal neurons } \\
\hline ChAT & Cholinergic interneuron & $99.0^{a}$ & Survive \\
\hline SS & SS/NPY/NOS interneuron & $1.9^{a}$ & Survive \\
\hline PARV & PARV interneuron & $17.8^{a}$ & Majority die \\
\hline CALB + & Matrix projection neuron & $63.8^{a}$ & Majority die \\
\hline \multicolumn{4}{|l|}{ Cortical neurons } \\
\hline Retrograde labeling & Layer 5 corticostriatal projection neuron & $100.0^{b}$ & Some die \\
\hline \multicolumn{4}{|l|}{$\begin{array}{l}\text { Other basal forebrain } \\
\text { neurons }\end{array}$} \\
\hline PARV & Globus pallidus projection neuron & $94.0^{a}$ & Some die \\
\hline ChAT & Nucleus basalis cholinergic neuron & $100.0^{a}$ & Survive \\
\hline
\end{tabular}

${ }^{a}$ Determined using double-label immunohistochemistry.

${ }^{b}$ Determined using retrograde labeling combined with immunolabeling.
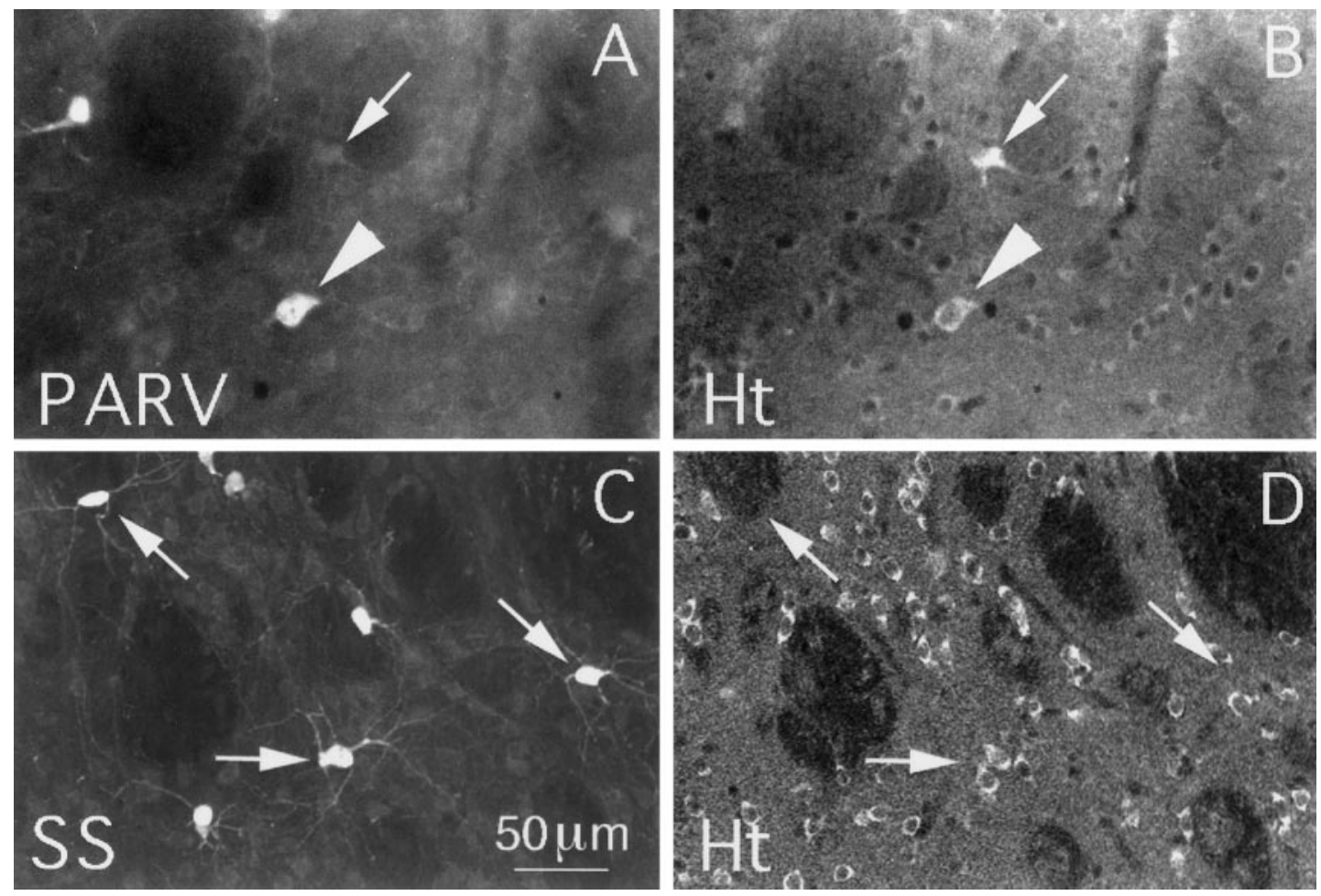

Figure 6. Huntingtin $(H t)$ localization in striatal parvalbuminergic or somatostatinergic interneurons in rat. Striatal tissue was double-labeled for parvalbumin $(P A R V)(A)$ and huntingtin $(B)$ or for somatostatin $(S S)(C)$ and huntingtin $(D)$ and viewed using epi-illumination fluorescence microscopy $(A, B)$ or CLSM $(C, D)$. $A$ and $B$ show several large perikarya that intensely labeled for parvalbumin in $A$, one of which is intensely labeled for huntingtin in $B$ (arrowhead). The arrows in $A$ and $B$ indicate a perikaryon that is unlabeled for PARV but intensely labeled for huntingtin. Many medium-sized perikarya that are unlabeled for parvalbumin in $A$ but are moderately labeled for huntingtin are also evident in $B$. $C$ and $D$ show several perikarya that are intensely labeled for somatostatin in $C$ but not labeled for huntingtin in $D$ (arrows). Many other medium-sized neuronal perikarya are labeled for huntingtin in $D$, but none of these are labeled for somatostatin in $C$. The mAb2168 anti-huntingtin antibody and the TSA method were used to label the tissue shown in $B$ and $D$. Magnification is the same in $A-D$.

striatal interneurons were largely devoid of huntingtin, and only a small fraction of the parvalbuminergic striatal interneurons were rich in huntingtin. Finally, our immunohistochemical and singlecell RT-PCR data show that many striatal projection neurons contain high levels of HD protein and message, whereas many others contain undetectable levels of both. As discussed further below and summarized in Tables 1 and 2, these results indicate that the localization of huntingtin within striatum in particular and telencephalon in general is not consistently correlated with cellular vulnerability in HD (Sharp and Ross, 1996).

\section{Comparison with previous findings by others}

The present results confirm previous findings that large neurons in cortex (particularly layer 5 pyramidal neurons), striatum, globus pallidus, and basal telencephalon in primates and rodents are rich in huntingtin (Gutekunst et al., 1995; Landwehrmeyer et al., 1995; Trottier et al., 1995; Gourfinkel-An et al., 1997). There have been conflicting reports, however, on the localization of huntingtin in cholinergic striatal interneurons and its relative abundance in patch versus matrix striatal projection neurons (Table 3). Some 

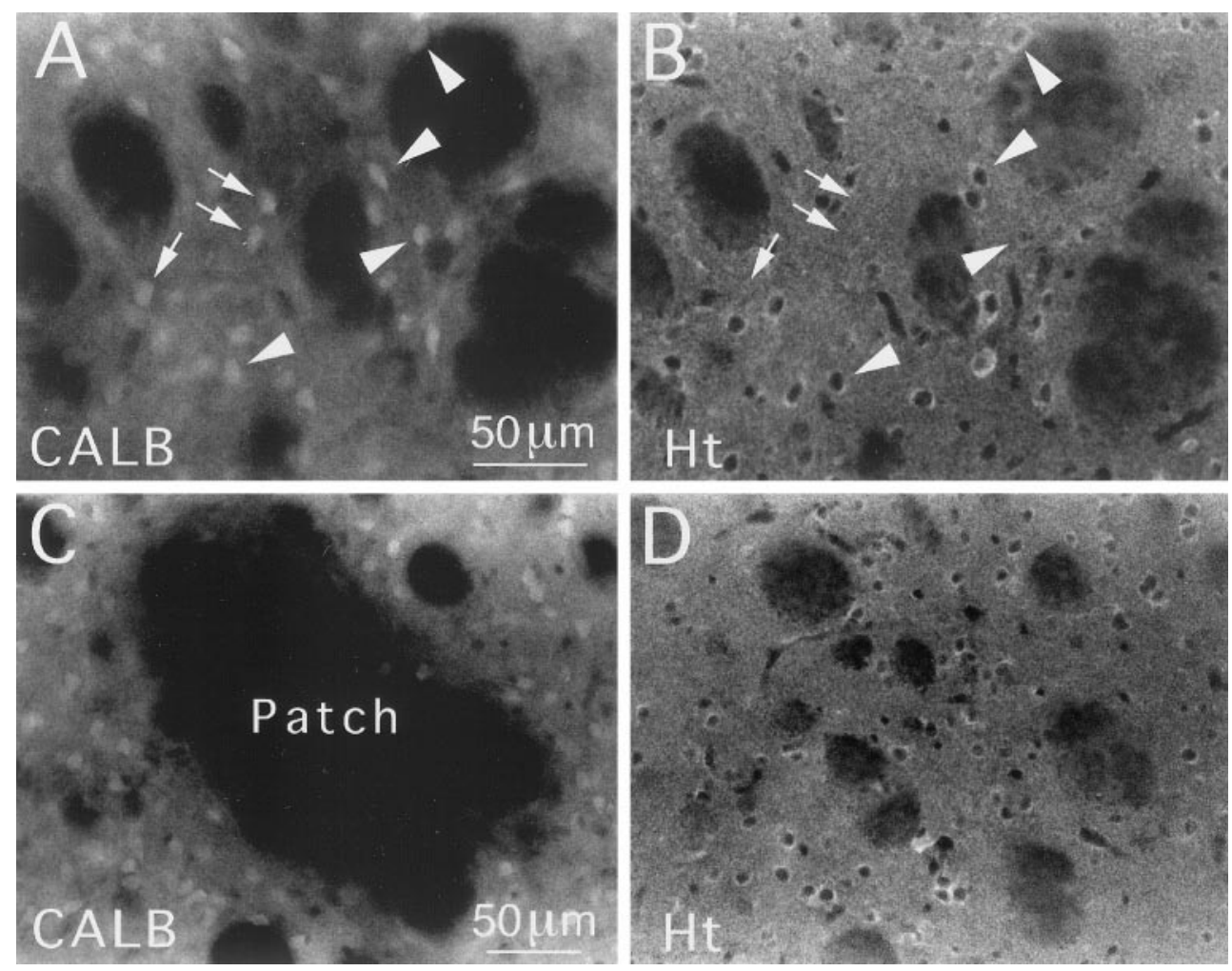

Figure 7. Huntingtin $(\mathrm{Ht})$ localization in striatal projection neurons in rat. Striatal tissue was double-labeled for calbindin $(A, C)$ and huntingtin $(B, D)$ and viewed using epi-illumination fluorescence microscopy. $A$ and $B$ show many mediumsized neuronal perikarya that are intensely labeled for calbindin $(C A L B)$ in $A$ and moderately labeled for huntingtin in $B$ (arrowheads), and some other mediumsized neuronal perikarya that are labeled for calbindin in $A$ but unlabeled for huntingtin in $B$ (arrows). $C$ shows a calbindinpoor patch that is largely devoid of perikaryal or neuropil labeling for calbindin. As shown in $D$, medium-sized neuronal perikarya labeled for huntingtin appear as abundant and as well labeled in the patch as in the matrix compartment. The mAb2166 anti-huntingtin antibody and the TSA method were used to label the tissue shown in $B$ and $D$. Magnification in $A$ as in $B$; magnification in $C$ as in $D$.

Table 2. Summary of present data on frequency of HD gene mRNA in defined types of striatal projection neurons in rats in relation to published information on the vulnerability of these same neuron types in $\mathrm{HD}$

\begin{tabular}{llll} 
Marker & Projection target & $\begin{array}{l}\% \text { containing } \\
\mathrm{Ht}\end{array}$ & Survival in HD \\
\hline SP & $\begin{array}{c}\text { Entopenduncular } \\
\text { nucleus }\end{array}$ & $90.0^{a}$ & Majority die slowly \\
ENK & Globus pallidus & $56.3^{a}$ & Majority die rapidly \\
SP/ENK & Substantia nigra & $56.0^{a}$ & Majority die rapidly \\
All combined & & $62.7^{a}$ & Majority die \\
\hline
\end{tabular}

${ }^{a}$ Determined using single-cell RT-PCR.

authors have reported that cholinergic striatal interneurons are devoid of or poor in huntingtin (Ferrante et al., 1997; Kosinski et al., 1997). In contrast, we found by both immunolabeling and single-cell RT-PCR that cholinergic striatal interneurons are rich in huntingtin and account for the vast majority of large striatal neurons that are intensely rich in huntingtin, as some previous authors had speculated (Gutekunst et al., 1995; Bhide et al., 1996). Our findings are also consistent with in situ hybridization histochemistry data in humans showing that large striatal neurons that are likely to include cholinergic interneurons contain readily detectable mRNA for the HD gene (Landwehrmeyer et al., 1995). The basis of the discrepancies between our immunohistochemical findings and those of some other groups for striatal cholinergic interneurons is uncertain, but the differences may relate to differences in antisera specificity and/or possible differences between cholinergic neurons and other striatal neuron types in the post-translational processing of huntingtin. Our single-cell RT-PCR data and the published in situ hybridization data, however, are not subject to such uncertainties. Thus, the available data support the view that cholinergic striatal interneu- rons contain high levels of huntingtin protein, although they may process it differently than do other neurons.

With respect to the localization of huntingtin in patch versus matrix striatal projection neurons (Table 3 ), one previous study in humans (Gutekunst et al., 1995) and one in rats (Kosinski et al., 1997) reported that patch neurons are richer than matrix neurons in huntingtin, whereas two other studies in humans reported that regions of striatum that may correspond to striosomes are poorer in perikaryal and neuropil labeling for huntingtin than are surrounding striatal regions (Ferrante et al., 1997; Sapp et al., 1997). We did not observe any differences between patch and matrix striatal compartments in rats, which is in accord with a previous in situ hybridization histochemistry study (Landwehrmeyer et al., 1995) and a previous immunohistochemical study (Bhide et al., 1996). As in the case of striatal cholinergic interneurons, these discrepancies in immunohistochemical findings may be attributable to differences in antisera specificity and/or to possible differences among striatal neuron types in the processing of huntingtin. The in situ hybridization data, however, are not subject to such uncertainties. Thus, taken together, the data do not support a clear difference between striatal patch and matrix neurons in huntingtin localization. It remains controversial whether patch or matrix projection neurons, if either, are more vulnerable in HD (Ferrante et al., 1986, 1987a,b; Kowall et al., 1987; Seto-Ohshima et al., 1988; Hedreen and Folstein, 1995).

Our finding that parvalbuminergic striatal neurons are typically moderate or poor in huntingtin is consistent with a previous report (Table 3 ) that also used parvalbumin immunolabeling to identify this type of large GABAergic interneuron in rat striatum (Kosinski et al., 1997). Because diaphorase, NOS, and somatostatin are largely found in the same striatal neurons (FigueredoCardenas et al., 1996), our finding that somatostatinergic neurons are largely devoid of huntingtin is consistent with previous reports that striatal neurons containing diaphorase or NOS in rats 

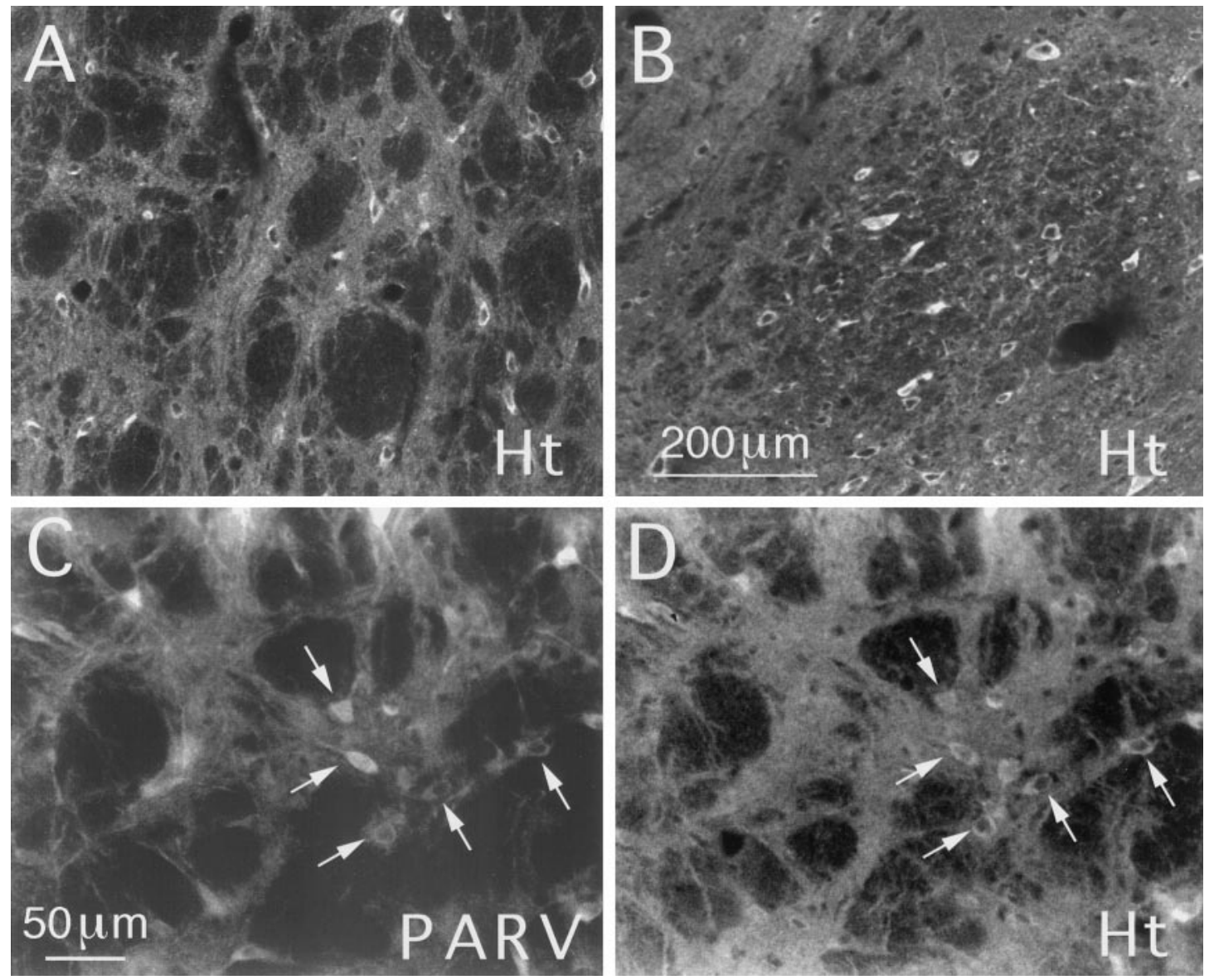

Figure 8. Huntingtin $(\mathrm{Ht})$ localization in the typically large neurons of the globus pallidus and entopeduncular nucleus in rat. Scattered large neurons intensely labeled for huntingtin in globus pallidus and the basal nucleus of Meynert, as viewed with CLSM, are shown in $A$ and $B$, respectively. $C$ and $D$ show a field of view of globus pallidus in tissue double-labeled for parvalbumin $(P A R V)(C)$ and huntingtin $(D)$, as viewed using epi-illumination fluorescence microscopy. Note that many pallidal neurons labeled for parvalbumin in $C$ are also labeled for huntingtin in $D$ (arrows). The TSA method and the following antibodies were used to obtain the anti-huntingtin labeling shown in these images: $\mathrm{mAb} 2170(A, B)$; $\mathrm{mAb} 2168(D)$. Magnification in $A$ as in $B$; magnification in $C$ as in $D$.

and humans are devoid of huntingtin (Ferrante et al., 1997; Kosinski et al., 1997) (Table 3). Because not all somatostatin neurons contain NOS or diaphorase (Figueredo-Cardenas et al., 1996), however, our findings show that striatal interneurons containing any combination of somatostatin, NOS, diaphorase, and neuropeptide Y are typically devoid of immunodetectable huntingtin. Finally, our finding that not all striatal projection neurons contain detectable huntingtin protein or message is consistent with previous reports in rats (Kosinski et al., 1997) and humans (Ferrante et al., 1997). Our RT-PCR studies further suggest that striatal projection neuron types differ in their content of huntingtin message and protein, because huntingtin message was much more commonly present among the SP type than the ENK and $\mathrm{SP} / \mathrm{ENK}$ types of striatal projection neuron. Data from in situ hybridization studies in humans are consistent with our findings in rats, in that they show heterogeneity among medium-sized striatal projection neurons (the vast majority of which are projection neurons) in their level of expression of huntingtin mRNA (Landwehrmeyer et al., 1995).

\section{Implications for the pathogenesis of HD}

The finding that striatal neurons are not uniquely enriched in huntingtin as compared with neurons in other parts of the brain has left it unclear why the striatum is the major site of brain pathology in HD. Assuming that our findings in rats can be generalized to humans, and because the gene mutation in HD does not seem to significantly alter the regional or cellular expression of huntingtin or its mRNA (Aronin et al., 1995; Landwehrmeyer et al., 1995; Schilling et al., 1995; Trottier et al., 1995; Bhide et al., 1996; Gourfinkel-An et al., 1997; Sapp et al., 1997), our findings raise additional uncertainty about how the HD mutation selectively leads to the greater vulnerability of striatal projection neurons as compared with striatal interneurons (Table 1). For example, cholinergic interneurons do not die in HD (Kowall et al., 1987), yet they appear to be richer in huntingtin than are striatal projection neurons, many of which contain no detectable huntingtin protein or message. Even among projection neuron types, our single-cell RT-PCR data indicate that the type of striatal projection neuron that is most vulnerable in $\mathrm{HD}$, the ENK + type (which projects mainly to the external pallidal segment, the correspondent of the rat globus pallidus), is poorer in huntingtin mRNA than is the less vulnerable type of projection neuron, the SP+ type (which projects heavily to the internal pallidal segment, the correspondent of the rat entopeduncular nucleus) (Reiner et al., 1988; Albin et al., 1990a; Richfield and Herkenham, 1994; Richfield et al., 1995). In addition, we found that presumptive striatonigral projections neurons (i.e., those 


\begin{tabular}{|c|c|c|c|c|c|c|c|}
\hline Authors of study & $\begin{array}{l}\text { Amino acid sequence } \\
\text { target of antisera }\end{array}$ & $\begin{array}{l}\text { Species } \\
\text { studied }\end{array}$ & $\begin{array}{l}\text { Cholinergic } \\
\text { interneurons }\end{array}$ & $\begin{array}{l}\text { Parvalbumin } \\
\text { interneurons }\end{array}$ & $\begin{array}{l}\mathrm{SS} / \mathrm{NPY} / \mathrm{NOS} \\
\text { interneurons }\end{array}$ & $\begin{array}{l}\text { Calbindinergic } \\
\text { projection neurons }\end{array}$ & Patch vs matrix \\
\hline Present paper & $\begin{array}{l}\text { aa181-812 } \\
\text { aa1247-1646 } \\
\text { aa2416-2541 }\end{array}$ & Rat & Rich in $\mathrm{Ht}$ & $\begin{array}{l}\text { Minority rich in } \\
\mathrm{Ht} \text {, majority } \\
\text { poor in } \mathrm{Ht}\end{array}$ & $\begin{array}{l}\text { Vast majority } \\
\text { devoid of } \mathrm{Ht}\end{array}$ & $\begin{array}{l}65 \% \text { moderate in } \mathrm{Ht} \text {; } \\
\text { remainder devoid } \\
\text { of } \mathrm{Ht}\end{array}$ & $\begin{array}{l}\text { Patch same as } \\
\text { matrix }\end{array}$ \\
\hline Kosinski et al., 1997 & aa1981-2580 & Rat & Poor in $\mathrm{Ht}$ & $\begin{array}{l}\text { Minority rich in } \\
\mathrm{Ht} \text {, majority } \\
\text { poor in } \mathrm{Ht}\end{array}$ & $\begin{array}{l}\text { Vast majority } \\
\text { devoid of } \mathrm{Ht}\end{array}$ & $\begin{array}{l}\text { Approximately } 90 \% \\
\text { moderate to rich in } \\
\mathrm{Ht} \text {; remainder de- } \\
\text { void of } \mathrm{Ht}\end{array}$ & $\begin{array}{l}\text { Patch richer than } \\
\text { matrix }\end{array}$ \\
\hline Ferrante et al., 1997 & aa549-679 & Human & $\begin{array}{l}\text { Poor in or } \\
\text { devoid of } \\
\mathrm{Ht}\end{array}$ & Not done & Devoid of $\mathrm{Ht}$ & $\begin{array}{l}\text { Approximately half } \\
\text { moderate in } \mathrm{Ht} \text {; } \\
\text { remainder devoid } \\
\text { of } \mathrm{Ht}\end{array}$ & $\begin{array}{l}\text { Patch poorer than } \\
\text { matrix }\end{array}$ \\
\hline Sapp et al., 1997 & aa585-745 & Human & $\begin{array}{l}\text { Large neurons } \\
\text { labeled for } \\
\text { Ht; unclear } \\
\text { how in- } \\
\text { tensely }\end{array}$ & Not done & Not done & $\begin{array}{l}\text { Many contain } \mathrm{Ht} \text {; } \\
\text { unclear how many } \\
\text { or how intensely }\end{array}$ & $\begin{array}{l}\text { Patch poorer than } \\
\text { matrix }\end{array}$ \\
\hline Bhide et al., 1996 & aa1-17 & Mouse & $\begin{array}{l}\text { Presumptive } \\
\text { cholinergic } \\
\text { neurons } \\
\text { rich in } \mathrm{Ht}\end{array}$ & Not done & Not done & $\begin{array}{l}\text { Many or all moderate } \\
\text { in } \mathrm{Ht}\end{array}$ & $\begin{array}{l}\text { Patch same as } \\
\text { matrix }\end{array}$ \\
\hline Gutekunst et al., 1995 & aa549-679 & $\begin{array}{l}\text { Rat, monkey, } \\
\text { humans }\end{array}$ & $\begin{array}{l}\text { Presumptive } \\
\text { cholinergic } \\
\text { neurons } \\
\text { rich in } \mathrm{Ht}\end{array}$ & Not done & Not done & $\begin{array}{l}\text { Many or all moderate } \\
\text { in } \mathrm{Ht}\end{array}$ & $\begin{array}{l}\text { Presumed patch } \\
\text { richer than ma- } \\
\text { trix in human }\end{array}$ \\
\hline
\end{tabular}

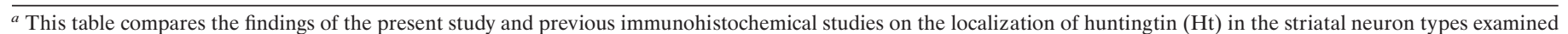
in the present study.

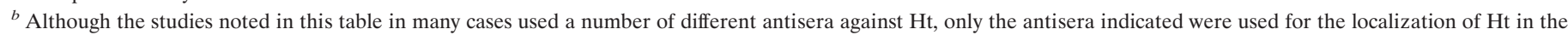
neuronal cell types of relevance to this table.

containing SP and ENK), which are as vulnerable as ENK+ neurons in $\mathrm{HD}$, are also poor in message for huntingtin. There is not, however, a strictly inverse relationship between huntingtin abundance and neuronal vulnerability. Somatostatinergic striatal interneurons, which survive well in HD, are largely devoid of huntingtin, whereas parvalbuminergic striatal interneurons, which appear to be as vulnerable as the projection neurons (Harrington and Kowall, 1991; Ferrer et al., 1994), are often rich to moderate in huntingtin. Finally, cortical pyramidal, pallidal, and basal forebrain cholinergic neurons all are rich in huntingtin, but are much less vulnerable in HD than are striatal projection neurons (Sharp and Ross, 1996). Thus, the level of huntingtin in telencephalic neurons does not by itself appear to explain why certain types of neurons die (Sharp et al., 1995; Gourfinkel-An et al., 1997).

A possible way in which the HD mutation might act to kill some neurons that contain it but not others is if the mutated protein interacts with cell type-specific proteins that are unique to vulnerable neurons. For example, cell-type specific proteolytic enzymes, nuclear transport proteins, and aggregation factors may cause cell type-specific accumulation of pathogenic intranuclear inclusions containing the N-terminal fragment of mutated huntingtin. Such intranuclear inclusions have been reported to occur in human HD victims and in a transgenic mouse model of HD, and it has been proposed that they may underlie HD pathogenesis (Davies et al., 1997; DiFiglia et al., 1997). Nonetheless, although a number of huntingtin-interacting proteins have been identified (Li et al., 1995; Burke et al., 1996; Kalchman et al., 1996, 1997; Wanker et al., 1997), none of these appears to be cell type specific. Thus, there is presently no clear evidence for this as the basis of the specificity of HD cell loss.

Our finding that cortical layer $\mathrm{V}$ pyramidal neurons are uniformly rich in huntingtin raises an intriguing possibility. Many layer V pyramidal neurons, as well as layer III cortical neurons, project to striatum (Goldman-Rakic and Selemon, 1986; Wilson, 1987; Cowan and Wilson, 1994; Kincaid and Wilson, 1996). If the gene defect somehow promotes excessive glutamate release by the striatal terminals of these neurons, then HD pathogenesis could involve excitotoxic destruction of striatal neurons. It is possible, in fact, that the neuronal intranuclear inclusions that are observed in cortical neurons in HD and in transgenic HD mice might be involved in a perturbation of corticostriatal neuron function that has excitotoxic consequences, for example by decreasing transcription of glutamate autoreceptors that dampen glutamate release (Mangiarini et al., 1996; Davies et al., 1997; DiFiglia et al., 1997; Cha et al., 1998). Several additional facts are consistent with the possibility of corticostriatal excitotoxicity in HD. First, cholinergic and somatostatinergic striatal interneurons are poor in cortical input and glutamatergic receptors, whereas striatal projection neurons and parvalbuminergic interneurons are rich in both (Wilson, 1987; Kita et al., 1990; Lapper and Bolam, 1992; Petralia and Wenthold, 1992; Martin et al., 1993; Sato et al., 1993; Tallaksen-Greene and Albin, 1994, 1996; Chen and Reiner, 1996; Chen et al., 1996, 1997; Bernard et al., 1997). Second, the patterns of striatal damage in rats and primates after quinolinic acid injection into the striatum (Albin et al., 1990a,b, 1992; Beal et al., 1991; Bazzett et al., 1993, 1994; FigueredoCardenas et al., 1994, 1997, 1998), after global ischemia (Ches- 
selet et al., 1990; Uemura et al., 1990), and after systemic administration of mitochondrial toxins such as 3-nitroproprionic (Beal, 1992; Beal et al., 1993a,b; Browne et al., 1997), all of which are thought to act via glutamate receptor-mediated excitotoxicity, closely resemble those in HD. Third, glutamate receptor-bearing neurons are lost in HD (Young et al., 1988; Arzberger et al., 1997). Fourth, genotypic variation in the GluR6-type kainate receptor subunit is associated with age of HD onset (Rubinsztein et al., 1997). Thus, the HD gene defect may act to render corticostriatal neurons destructive rather than to render striatal neurons vulnerable.

If our interpretation is true, then it raises the question as to why the striatum among cortical pyramidal neuron target areas is the most vulnerable in HD. As already discussed for the different types of striatal neurons, a critical determinant of the vulnerability of other cortical targets in HD may be the extent to which they receive input from cortical or any other huntingtin-rich glutamatergic neurons and the extent to which they possess certain types of glutamate receptors. Although the relative vulnerability in HD of various regions outside of the basal ganglia has not been systematically evaluated, a number of cortical targets, including cortical layers III, V, and VI, substantia nigra, globus pallidus, and subthalamic nucleus, undergo cell loss in HD, but less so than does striatum (Byers et al., 1983; Vonsattel et al., 1985; De La Monte et al., 1988; Cudkowicz and Kowall, 1990; Sharp and Ross, 1996). It is possible, for example, that malfunction of glutamatergic cortical input arising from layer 5 neurons and/or subthalamic terminals in globus pallidus in HD may be responsible for the death of the pallidal neurons on which they synapse (Kitai and Kita, 1987). Similarly, the local collaterals of layer 5 cortical neurons may contribute to the death of layer 6 cortical neurons observed in HD. Nonetheless, this hypothesis of HD pathogenesis is likely to be overly simplified, because it does not readily explain the dorsomedial to ventrolateral gradient of cell loss observed in HD striatum, nor does it take into account how striatal neurons might affect each other's survival or how intercell-type differences in the ability to combat the neurodegenerative process might shape the spatial and cellular pattern of cell death in HD (Medina et al., 1996; Bernier and Parent, 1998; Figueredo-Cardenas et al., 1998).

\section{REFERENCES}

Adams J (1992) Biotin amplification of biotin and horseradish peroxidase signals in histochemical stains. J Histochem Cytochem 40:1457-1463.

Albin RL, Tagle DA (1995) Genetics and molecular biology of Huntington's disease. Trends Neurosci 18:11-14.

Albin RL, Reiner A, Anderson KD, Penney JB, Young AB (1990a) Striatal and nigral neuron subpopulations in rigid Huntington's disease: implications for the functional anatomy of chorea and rigidity-akinesia. Ann Neurol 27:357-365.

Albin RL, Young AB, Penney JB, Handelin B, Balfour R, Anderson KD, Markel DS, Tourtellotte WW, Reiner A (1990b) Abnormalities of striatal projection neurons and $N$-methyl-D-aspartate receptors in presymptomatic Huntington's disease. N Engl J Med 332:1923-1298.

Albin RL, Reiner A, Anderson KD, Dure LS IV, Handelin B, Balfour R, Whetsell Jr WO, Penney JB, Young AB (1992) Preferential loss of striato-external pallidal projection neurons in presymptomatic Huntington's disease. Ann Neurol 31:425-430.

Anderson KD, Reiner A (1990) The extensive co-occurrence of substance $\mathrm{P}$ and dynorphin in striatal projection neurons: an evolutionarily conserved feature of basal ganglia organization. J Comp Neurol 295:339-369.

Anderson KD, Reiner A (1991) Immunohistochemical localization of DARPP-32 in striatal projection neurons and striatal interneurons: implications for the localization of D1 dopamine receptors on different types of striatal neurons. Brain Res 568:235-243.

Aronin N, Chase K, Christine Y, Sapp E, Schwartz C, Matta N, Konreich R, Landwehrmeyer B, Bird E, Beal MF, Vonsattel JP, Smith T, Carraway R, Boyce FM, Young AB, Penney JB, DiFiglia M (1995) CAG Expansion affects the expression of mutant Huntingtin in the Huntington's disease brain. Neuron 15:1193-1201.

Arzberger T, Krampfl K, Leimgruber S, Weindl A (1997) Changes of NMDA receptor subunit (NR1, NR2B) and glutamate transporter (GLT1) mRNA expression in Huntington's disease: an in situ hybridization study. J Neuropathol Exp Neurol 56:440-454.

Bazzett TJ, Becker JB, Katz KW, Albin RL (1993) Chronic intrastriatal dialytic administration of quinolinic acid produces selective neural degeneration. Exp Neurol 120:177-185.

Bazzett TJ, Becker JB, Falik RC, Albin RL (1994) Chronic intrastriatal quinolinic acid produces reversible changes in perikaryal calbindin and parvalbumin immunoreactivity. Neuroscience 60:837-841.

Beal MF (1992) Does impairment of energy metabolism result in excitotoxic neuronal death in neurodegenerative illnesses? Ann Neurol 31:119-130.

Beal MF, Kowall NW, Ellison DW, Mazurek MF, Swartz KJ, Martin JB (1986) Replication of the neurochemical characteristics of Huntington's disease by quinolinic acid. Nature 321:168-171.

Beal MF, Kowall NW, Swartz KJ, Ferrante RJ, Martin JB (1988) Systemic approaches to modifying quinolinic acid striatal lesions in rats. J Neurosci 8:3901-3908.

Beal MF, Ferrante RJ, Swartz KJ, Kowall NW (1991) Chronic quinolinic acid lesions in rats closely resemble Huntington's disease. J Neurosci 11:1649-1659.

Beal MF, Bradley TH, Koroshetz W (1993a) Do defects in mitochondrial energy metabolism underlie the pathology of neurodegenerative diseases? Trends Neurosci 16:125-131.

Beal MF, Brouillet E, Jenkins BG, Ferrante RJ, Kowall NW, Miller JM, Storey E, Srivastava R, Rosen BR, Hyman BT (1993b) Neurochemical and histologic characterization of striatal excitotoxic lesions produced by the mitochondrial toxin 3-nitroproprionic acid. J Neurosci 13:4181-4192.

Berghorn KA, Bonnett JH, Hoffman GE (1994) cFos immunoreactivity is enhanced with biotin amplification. J Histochem Cytochem 42:1635-1642.

Bernard V, Somogyi P, Bolam JP (1997) Cellular, subcellular, and subsynaptic distribution of AMPA-type glutamate receptor subunits in the neostriatum of the rat. J Neurosci 17:819-833.

Bernier PJ, Parent A (1998) The anti-apoptosis bcl-2 proto-oncogene is preferentially expressed in limbic structures of the primate brain. Neuroscience 82:635-640.

Bessert DA, Gutridge KL, Dunbar JC, Carlock LR (1995) The identification of a functional nuclear localization signal in the Huntington's disease protein. Mol Brain Res 33:165-173.

Bhide PG, Day M, Sapp E, Schwartz C, Sheth A, Kim J, Young AB, Penney J, Golden J, Aronin N, DiFiglia M (1996) Expression of normal and mutant huntingtin in the developing brain. J Neurosci 16:5523-5535.

Bobrow MN, Harris TD, Shaughnessy KJ, Litt GJ (1989) Catalyzed reported deposition, a novel method of signal amplification, application to immunoassays. J Immunol Methods 125:279-285.

Bobrow MN, Shaughnessy KJ, Litt GJ (1991) Catalyzed reported deposition, a novel method of signal amplification. II. Application to membrane assays. J Immunol Methods 137:103-112.

Browne SE, Bowling AC, MacGarvey U, Baik MJ, Berger SC, Muquit MMK, Bird ED, Beal MF (1997) Oxidative damage and metabolic dysfunction in Huntington's disease: selective vulnerability of the basal ganglia. Ann Neurol 41:646-653.

Bruyn GW, Went LN (1986) Huntington's chorea. In: Handbook of clinical neurology (Vinken PJ, Bruyn GW, Klawans HL, eds), pp 267-313. Amsterdam: Elsevier.

Burke JR, Enghild JJ, Martin ME, You YS, Myers RM, Roses AD, Vance JM, Strittmatter WJ (1996) Huntingtin and DRPLA proteins selectively interact with the enzyme GAPDH. Nat Med 2:347-350.

Byers RK, Gilles FH, Fung C (1983) Huntington's disease in children. Neuropathological study of four cases. Neurology 23:561-569.

Cha JHJ, Kosinski CM, Kerner JA, Alsdorf SA, Mangiarini L, Davies SW, Penney JB, Bates GP, Young AB (1998) Altered brain neurotransmitter receptors in transgenic mice expressing a portion of an 
abnormal human Huntington disease gene. Proc Natl Acad Sci USA 95:6480-6485.

Chen Q, Reiner A (1996) Cellular distribution of the NMDA receptor NR2A/2B subunits in the rat striatum. Brain Res 743:346-352.

Chen Q, Veenman CL, Reiner A (1996) Cellular expression of ionotropic glutamate receptor subunits on specific striatal neuron types and its implication for striatal vulnerability in glutamate receptor-mediated excitotoxicity. Neuroscience 73:715-731.

Chen Q, Veenman CL, Knopp K, Yan Z, Medina L, Song WJ, Surmeier DJ, Reiner A (1997) Evidence for the preferential localization of GluR1 subunits of AMPA receptors to the dendritic spines of medium spiny neurons in rat striatum. Neuroscience 83:749-761.

Chesselet MF, Lin CS, Polsky K, Jin BK (1990) Ischemic damage in the striatum of adults gerbils: relative sparing of somatostatinergic and cholinergic interneurons contrasts with loss of efferent neurons. Exp Neurol 110:209-218.

Cimino GD, Metchette K, Isaacs ST, Zhu YS (1990) More false positive problems (letter/comment). Nature 345:773-774.

Cowan RL, CJ Wilson (1994) Spontaneous firing patterns and axonal projections of single corticostriatal neurons in the rat medial agranular cortex. J Neurophysiol 71:17-32.

Cowan RL, Wilson CJ, Emson PC, Heizmann CW (1990) Parvalbumincontaining GABAergic interneurons in the rat neostriatum. J Comp Neurol 302:197-205

Cudkowicz M, Kowall NS (1990) Degeneration of pyramidal projection neurons in Huntington's disease cortex. Ann Neurol 27:200-204.

Davies SW, Turmaine M, Cozens BA, DiFiglia M, Sharp AH, Ross CA, Scherzinger E, Wanker EE, Mangiarini L, Bates GP (1997) Formation of neuronal intranuclear inclusions underlies the neurological dysfunction in mice transgenic for the HD mutation. Cell 90:537-548.

De La Monte SM, Vonsattel JP, Richardson Jr EP (1988) Morphometric demonstrations of atrophic changes in the cerebral cortex, white matter, and neostriatum in Huntington's disease. J Neuropathol Exp Neurol 44:516-525.

DiFiglia M, Sapp E, Chase K, Schwarts C, Meloni A, Young C, Martin E, Vonsattel JP, Carraway R, Reeves SA, Boyce FM, Aronin N (1995) Huntingtin is a cytoplasmatic protein associated with vesicles in human and rat brain neurons. Neuron 14:1075-1081.

DiFiglia M, Sapp E, Chase KO, Davies SW, Bates GP, Vonsattel JP, Aronin JP (1997) Aggregation of huntingtin in neuronal intranuclear inclusions and dystrophic neurites in brain. Science 277:1990-1993.

Evers P, Eylings HBM (1994) Microwave-stimulated antigen retrieval is $\mathrm{pH}$ and temperature dependent. J Histochem Cytochem 42:1555-1563.

Ferrante RJ, Kowall NW, Beal MF, Richardson Jr EP, Bird ED, Martin JB (1985) Selective sparing of a class of striatal neurons in Huntington's disease. Science 230:561-563.

Ferrante RJ, Kowall NW, Richardson EP, Bird ED, Martin JB (1986) Topography of enkephalin, substance $\mathrm{P}$, and acetylcholinesterase in Huntington's disease striatum. Neurosci Lett 71:283-288.

Ferrante RJ, Kowall NW, Beal MF, Martin JB, Bird ED, Richardson Jr EP (1987a) Morphological and histochemical characteristics of a spared subset of striatal neurons in Huntington's disease. J Neuropathol Exp Neurol 46:12-27.

Ferrante RJ, Beal MF, Kowall NW, Richardson Jr EP, Martin JB (1987b) Sparing of acetylcholinesterase-containing striatal neurons in Huntington's disease. Brain Res 411:162-166.

Ferrante RJ, Gutenkust CA, Persichetti F, McNeil SM, Kowall NW, Gusella JF, MacDonald ME, Beal MF, Hersch SM (1997) Heterogeneous topographic and cellular distribution of Huntingtin expression in the normal human neostriatum. J Neurosci 17:3052-3063.

Ferrer I, Kulisevsky J, Gonzalez G, Escartin A, Chivite A, Casas R (1994) Parvalbumin-immunoreactive neurons in the cerebral cortex and striatum in Huntington's disease. Neurodegeneration 3:169-173.

Figueredo-Cardenas G, Anderson KD, Chen Q, Veeman CL, Reiner A (1994) Relative survival of striatal projection neurons and interneurons after intrastriatal injection of quinolinic acid in rats. Exp Neurol 129:37-56.

Figueredo-Cardenas G, Morello M, Sancesario G, Bernardi G, Reiner A (1996) Colocalization of somatostatin, neuropeptide Y, NADPHdiaphorase and neuronal nitric oxide synthase in striatal interneurons in rats. Brain Res 735:317-324.

Figueredo-Cardenas G, Chen Q, Reiner A (1997) Age-dependent differences in survival of striatal somatostatin-NPY-NADPH-diaphorasecontaining interneurons versus striatal projection neurons after intrastriatal injection of quinolinic acid in rats. Exp Neurol 146:444-457.
Figueredo-Cardenas G, Harris C, Anderson KD, Reiner A (1998) Relative resistance of striatal neurons containing calbindin or parvalbumin to quinolinic acid-mediated excitotoxicity compared to other striatal neuron types. Exp Neurol 149:356-372.

Goldman-Rakic P, Selemon LD (1986) Topography of corticostriatal projections in nonhuman primates and implications for functional parcellation of the neostriatum. In: Cerebral cortex, Vol 5 (Jones EG, Peters A, eds), pp 447-466. New York: Plenum.

Gourfinkel-An I, Cancel G, Trottier Y, Devys D, Tora L, Lutz Y, Imbert G, Saudou F, Stevanin G, Agid Y, Brice A, Mandel JL, Hirsch EC (1997) Differential distribution of the normal and mutated forms of huntingtin in the human brain. Ann Neurol 42:712-719.

Gutekunst CA, Levey AI, Heilman CJ, Whaley WL, Yi H, Nash NR, Rees HD, Madden JJ, Hersh SM (1995) Identification and localization on huntingtin in brain and human lymphoblastoid cell lines with anti-fusion protein antibodies. Proc Natl Acad Sci USA 92:8710-8714.

Harrington KM, Kowall NM (1991) Parvalbumin immunoreactive neurons resist degeneration in Huntington's disease striatum. J Neuropathol Expl Neurol 50:309.

Hedreen JC, Folstein SE (1995) Early loss of neostriatal striosome neurons in Huntington's disease. J Neuropathol Exp Neurol 54:105-120.

Hedreen JC, Peyser CE, Folstein SE, Ross CA (1991) Neuronal loss in layers V and VI of cerebral cortex in Huntington's disease. Neurosci Lett 133:257-261.

Huang Q, Zhou D, Sapp E, Aizawa H, Ge P, Bird ED, Vonsattel JP, DiFiglia M (1995) Quinolinic acid induced increases in calbindin D28k immunoreactivity in rat striatal neurons in vivo and in vitro mimic the pattern seen in Huntington's disease. Neuroscience 65:397-407.

Huntington's Disease Collaborative Research Group (1993) A novel gene containing a trinucleotide repeat that is expanded and unstable on HD chromosome. Cell 72:971-983.

Kalchman MA, Graham RK, Xia G, Koide HB, Hodgson JG, Graham KC, Goldberg YP, Gietz RD, Pickart CM, Hayden MR (1996) Huntingtin is ubiquitinated and interacts with a specific ubiquitinconjugated enzyme. J Biol Chem 27:19385-19394.

Kalchman MA, Hoide HB, McCutcheon K, Graham RK, Nichol K, Nishiyama K, Kaemi-Esfarjani P, Lynn FC, Wellington C, Metzler M, Goldberg YP, Kanazawa I, Gietz RD, Hayden MR (1997) HIP1, a human homologue of $S$. cerevisiae Sla2p: interacts with membraneassociated huntingtin in the brain. Nat Genet 16:44-53.

Kawaguchi Y, Wilson CJ, Emson PC (1990) Projection subtypes of rat neostriatal matrix cells revealed by intracellular injection of biocytin. J Neurosci 10:3421-3438.

Kincaid AE, Wilson CJ (1996) Corticostriatal innervation of the patch and matrix in the rat neostriatum. J Comp Neurol 374:578-592.

Kita H, Kosaka T, Heizmann CW (1990) Parvalbumin-immunoreactive neurons in the rat neostriatum: a light and electron microscopic study. Brain Res 536:1-15.

Kitai ST, Kita H (1987) Anatomy and physiology of the subthalamic nucleus: a driving force of the basal ganglia. In: The basal ganglia II. Structure and function: current concepts (Carpenter MB, Jaraman A, eds), pp 357-373. New York: Plenum.

Kiyama H, Seto-Ohshima A, Emson PC (1990) Calbindin D28k as a marker for the degeneration of striatonigral pathway in Huntington's disease. Brain Res 525:209-214.

Kosinski CM, Cha JH, Young AB, Persichetti F, MacDonald M, Gusella JF, Penney Jr JB, Standaert DG (1997) Huntingtin immunoreactivity in the rat neostriatum: differential accumulation in projection and interneurons. Exp Neurol 144:239-247.

Kowall NW, Ferrante RJ, Martin JB (1987) Pattern of cell loss in Huntington's disease. Trends Neurosci 10:24-29.

Landwehrmeyer GB, McNeil SM, Dure IV LS, Ge P, Aizawa H, Huang Q, Ambrose CM, Duyao MP, Bird ED, Bonilla E, deYoung M, Avila-Gonzales AJ, Wexler NS, DiFiglia M, Gusella JF, MacDonald ME, Penney JB, Young AB, Vonsattel JP (1995) Huntington's disease gene: regional and cellular expression in brain of normal and affected individuals. Ann Neurol 37:218-230.

Lapper SR, Bolam JP (1992) Input from the frontal cortex and the parafascicular nucleus to cholinergic interneurons in the dorsal striatum of the rat. Neuroscience 51:533-545.

Li SH, Schilling G, Young III WS, Li XJ, Margolis RL, Stine OC, Wagster MV, Abbott MH, Franz ML, Ranen NG, Folstein SE, Hedreen JC, Ross CA (1993) Huntington's disease gene (IT15) is widely expressed in human and rat tissues. Neuron 11:985-993. 
Li XJ, Li SH, Sharp AH, Nucifora FC, Schilling Jr G, Lanahan A, Worley P, Snyder SH, Ross CA (1995) A huntingtin-associated protein enriched in brain with implications for pathology. Nature 378:398-402.

Mangiarini L, Sathasivam K, Seller M, Cozens B, Harper A, Hetherington C, Lawton M, Trottier Y, Lehrbach H, Davies SW, Bates G (1996) Exon 1 of the HD gene with an expanded CAG repeat is sufficient to cause a progressive neurological phenotype in transgenic mice. Cell 87:493-506.

Martin LJ, Blackstone CD, Levey AI, Huganir RL, Price DL (1993) AMPA glutamate receptor subunits are differentially distributed in rat brain. Neuroscience 53:327-358.

Medina L, Figueredo-Cardenas G, Reiner A (1996) Differential abundance of superoxide dismutase in interneurons versus projection neurons in patch versus matrix neurons in monkey striatum. Brain Res 708:59-70.

Petralia RS, Wenthold RJ (1992) Light and electron immunocytochemical localization of AMPA-selective glutamate receptors in the rat brain. J Comp Neurol 318:329-354.

Reiner A, Anderson KD (1990) The patterns of neurotransmitter and neuropeptide co-occurrence among striatal projection neurons: conclusions based on recent findings. Brain Res Rev 15:251-265.

Reiner A, Albin RL, Anderson KD, D'Amato CJ, Penney JB, Young AB (1988) Differential loss of striatal projection neurons in Huntington's disease. Proc Natl Acad Sci USA 85:5733-5737.

Richfield EK, Herkenham M (1994) Selective vulnerability in Huntington's disease: preferential loss of cannabinoid receptors in lateral globus pallidus. Ann Neurol 36:577-584.

Richfield EK, Maguire-Zeiss KA, Cox C, Gilmore J, Voorn P (1995) Reduced expression of preproenkephalin in striatal neurons from Huntington's disease patients. Ann Neurol 37:335-343.

Rubinsztein DC, Leggo J, Chiano M, Dodge A, Norbury G, Rosser E, Craufurd D (1997) Genotypes at the GlR6 kainate receptor locus are associated with variation in the age of onset of Huntington's disease. Proc Natl Acad Sci USA 94:3872-3876.

Sapp E, Schwarz C, Chase K, Bhide PG, Young AB, Penney J, Vonsattel JP, Aronin N, DiFiglia M (1997) Huntingtin localization in brains of normal and Huntington's disease patients. Ann Neurol 42:604-612.

Sato K, Kiyama H, Tohyama M (1993) The differential expression patterns of messenger RNAs encoding non-NMDA glutamate receptor subunits (GluR1-4) in the rat brain. Neuroscience 52:515-539.

Schilling G, Sharp AH, Loev SJ, Wagster MV, Li SH, Stine OC, Ross CA (1995) Expression of the Huntington's disease (IT15) protein product in HD patients. Hum Mol Genet 4:1365-1371.

Seto-Ohshima A, Emson PC, Lawson E, Mountjoy CQ, Carrasco LH (1988) Loss of matrix calcium binding protein containing neurons in Huntington's disease. Lancet 1:1252-1255.

Sharp AH, Ross CA (1996) Neurobiology of Huntington's disease. Neurobiol Dis 3:3-15.
Sharp AH, Loev SJ, Schiling G, Li SH, Li XJ, Bao J, Wagster MV, Kotzuk JA, Steiner JP, Lo A, Hedreen J, Sisodia S, Snyder SH, Dawson TM, Ryugo DDK, Ross CA (1995) Widespread expression of Huntington's disease gene (IT15) protein product. Neuron 14:1065-1074.

Storey E, Kowall NW, Finn SF, Mazurek MF, Beal MF (1992) The cortical lesion of Huntington's disease: further neurochemical characterization and reproduction of some of the histological and neurochemical features by $N$-methyl-D-aspartate. Ann Neurol 32:526-534.

Surmeier DJ, Eberwine J, Wilson CJ, Cao Y, Stefani A, Kitai ST (1992) Dopamine receptor subtypes colocalize in rat striatonigral neurons. Proc Natl Acad Sci USA 89:10178-10182.

Surmeier DJ, Song WJ, Yan Z (1996) Coordinated expression of dopamine receptors in neostriatal medium spiny neurons. J Neurosci 16:6579-6591.

Tallaksen-Greene SJ, Albin RL (1994) Localization of AMPA-selective excitatory amino acid receptor subunits in identified populations of striatal neurons. Neuroscience 61:509-519.

Tallaksen-Greene SJ, Albin RL (1996) Splice variants of glutamate receptor subunits 2 and 3 in striatal projection neurons. Neuroscience 75:1057-1064.

Trottier Y, Devys D, Imbert G, Saudou F, An I, Lutz Y, Weber C, Agid Y, Hirsch EC, Mandel JL (1995) Cellular localization of the Huntington's disease protein and discrimination of the normal and mutated form. Nat Genet 10:104-110.

Uemura Y, Kowall NW, Beal MF (1990) Selective sparing of NADPHdiaphorase-somatostatin-neuropeptide $\mathrm{Y}$ neurons in ischemic gerbil striatum. Ann Neurol 27:620-625.

Vonsattel JP, Myers RH, Stevens TJ, Ferrante RJ, Bird ED, Richardson EP (1985) Neuropathological classification of Huntington's disease. J Neuropathol Exp Neurol 44:559-577.

Wanker EE, Rivira C, Scherzinger E, Hasenbank R, Walter S, Tait D, Colicelli J, Lehrbach H (1997) HIP-I: a huntingtin-interacting protein isolated by the yeast two-hybrid system. Hum Mol Genet 6:487-495.

Wilson CJ (1987) Morphology and synaptic connections of crossed corticostriatal neurons in the rat. J Comp Neurol 263:567-580.

Wilson RS, Como PG, Garron DC, Klawans HL, Barr A, Klawans D (1987) Memory failure in Huntington's disease. J Clin Exp Neuropsychol 9a:147-154.

Wood JD, McLaughlin JC, Harper PS, Lowenstein PR, Jones AL (1996) Partial characterization of murine huntingtin and apparent variations in the subcellular localization of huntingtin in human, mouse and rat brain. Hum Mol Genet 5:481-487.

Young AB, Greenamyre JT, Hollingsworth Z, Albin R, D'Amato C, Shoulson I, Penney JB (1988) NMDA receptor losses in putamen from patients with Huntington's disease. Science 241:981-983. 